Article

\title{
Assessing the Impact of Investments in Cross-Border Pipelines on the Security of Gas Supply in the EU
}

\author{
Yassine Rqiq ${ }^{1}$, Jesus Beyza ${ }^{1}{ }^{(\mathbb{D},}$, Jose M. Yusta ${ }^{1, * \mathbb{C}}$ and Ricardo Bolado-Lavin ${ }^{2}$ \\ 1 Department of Electrical Engineering, University of Zaragoza, Maria de Luna 3, 50018 Zaragoza, Spain; \\ yassinerqiq@gmail.com (Y.R.); jbbcia4@hotmail.com (J.B.) \\ 2 European Commission-DG Joint Research Centre, Westerduinweg 3, NL-1755 LE Petten, The Netherlands; \\ ricardo.bolado-lavin@ec.europa.eu \\ * Correspondence: jmyusta@unizar.es; Tel.: +34-976761922
}

Received: 21 April 2020; Accepted: 3 June 2020; Published: 6 June 2020

\begin{abstract}
The European Union (EU) is highly dependent on external natural gas supplies and has experienced severe gas cuts in the past, mainly driven by the technical complexity of the high-pressure natural gas system and political instability in some of the supplier countries. Declining indigenous natural gas production and growing demand for gas in the EU has encouraged investments in cross-border transmission capacity to increase the sharing of resources between the member states, particularly in the aftermath of the Russia-Ukraine gas crisis in January 2009. This article models the EU interconnected natural gas system to assess the impact of investments in the gas transmission network by comparing the performance of the system for scenarios of 2009 and 2017, using a mathematical optimization approach. The model uses the technical data of the infrastructures, such as production, storage, regasification, and exchange capacity through cross-border pipelines, and proposes an optimal collaborative strategy which ensures the best possible coverage of overall demand. The actual peak demand situations of the extreme cases of 2009 and 2017 are analyzed under hypothetical supply crises caused by geopolitical or commercial disputes. The application of the proposed methodology leads to results which show that the investments made in this system do not decongest the cross-border pipeline network but improve the demand coverage. Countries such as Spain and Italy experience a lower impact on gas supply due to the variety of mechanisms available to cover their demand. Furthermore, the findings prove that cooperation facilitates the supply of demand in crisis situations.
\end{abstract}

Keywords: security of supply; natural gas networks; European Union

\section{Introduction}

Securing natural gas supply is becoming increasingly important in the global energy paradigm. According to the International Energy Agency (IEA), natural gas currently accounts for $22 \%$ of the energy used worldwide and generates $25 \%$ of the total electricity produced. Forecasts show that gas consumption will increase with the industry sector as the main driver of growth [1,2].

Gas infrastructures are even more relevant for energy security as gas-fired power plants are increasingly supporting the deployment of renewables for electricity generation in the energy transition. Furthermore, existing natural gas transmission pipelines are being considered to introduce hydrogen produced from renewable energy, which is a new energy vector with many end uses including power generation, transport, and industrial applications. Emerging power-to-gas technologies allow hydrogen to be produced from water and electricity and injected into the gas pipeline network, either directly or converted to synthetic natural gas or biomethane [3]. In this way, the gas system is also contributing to the decarbonization of the energy sector. 
One of the consequences of the rising gas consumption is increased seasonality, which results in higher congestion of gas infrastructures during winter. Investments to diversify supply systems and build new facilities are currently being made by countries to reverse the seasonality effect and avoid shortages due to technical limitations. For example, some projects are being developed to diversify natural gas suppliers and improve the European Union gas network infrastructure, which consists of 28 countries (hereinafter referred to as EU-28) and at certain points in the winter months the infrastructure use reaches $80 \%$ of total capacity. The pipeline congestion is not uniform throughout the gas system of the EU-28 since those member states closer to external supplier countries have the highest congestion $[4,5]$. Thus, there are initiatives under development to import liquefied natural gas (LNG) from the U.S., to increase the import capacity from third-party countries and to invest in regasification plants, among others [1].

To ensure the continued natural gas supply, the congestion of the transmission and storage infrastructure needs to be controlled to address crisis situations and mitigate their impact on natural gas demand. Natural gas supply shortages can be caused by natural events, commercial disputes, and geopolitical reasons or a combination of both and can directly affect end consumers and generate a crisis scenario [2].

In recent years, some studies have been carried out to determine the level of congestion of European Union (EU) gas infrastructure under hypothetical crises, examining the impact of gas disruption from Algeria or Russia. In [6], a disruption from Algeria is assessed for the natural gas supply of the EU in 2011, concluding that most countries would be able to meet their natural gas demand. More studies have focused on Russian gas disruptions, as a crisis that would cut off Russia's supply to Europe is the most challenging scenario [4]. While most EU countries would not be affected by the Russian disruptions, some Eastern European and Baltic countries remain vulnerable [7]. Different results of the studies can be observed. While in [8], Bulgaria, Czech Republic, Estonia, Finland, Latvia, and Lithuania seem to be at risk, in [9] an interruption of gas transit through Ukrainian pipelines would severely affect to Austria, Bulgaria, Bosnia-Herzegovina, Hungary, Serbia, Slovakia, with a reduction of consumption of $50-100 \%$ in 2015-2020, but less to the Czech Republic, Romania, Slovenia (20-50\%), Turkey, Croatia, and Poland (1-10\%). It is worth mentioning that the cases of Finland and the Baltic countries are quite different from other EU countries, as they are entirely dependent on direct gas supply from Russia.

When analyzing the role of cross-border interconnections, some research works coincide in pointing out the lack of interconnectors and pipelines as the main problem to solve possible supply crises in the EU gas transmission system, particularly in the Balkan and Eastern European countries [9]. Interconnectedness appears to be a central issue, and the removal of bottlenecks is critical to mitigating the gas supply crisis $[7,10]$. Additionally, the gas infrastructure must be more flexible to handle more than one predominant flow direction [11]. In this regard, the only work comparing the EU gas system between two dates shows an improvement in transmission capacity and the bi-directionality of the pipelines between 2009 and 2014 [12].

Gas networks operators have tools to simulate the operation of transmission infrastructures and carry out studies on supply security against possible contingencies and their impact on consumers. In the literature, there are dynamic simulation models of natural gas flow in transmission systems based on mathematical and probabilistic methods. Mathematical methods integrate the equations that govern gas networks to simulate its operation and determine the impact on the supply after a disturbance [13,14]. Meanwhile, the probabilistic model is based on the Monte Carlo method and examines the behavior of the network under different crisis scenarios through a high number of repetitions of a case study. Traditionally, there are two types of analysis techniques that evaluate the performance of a system against random disturbances: sequential and non-sequential. The sequential Monte Carlo method has been widely used to assess the reliability and response of natural gas networks $[6,15,16]$.

In addition, other studies have used specific software programs, such as PLEXOS ${ }^{\circledR}$ and SAInt (Scenario Analysis Interface for Energy Systems) [17-19]. These tools have been used to determine the 
influence of gas outages on the electricity prices of EU countries, as well as to simulate the operation of integrated gas and electricity networks $[17,19]$. Both software applications are equipped with simulation tools based on Monte Carlo techniques.

Although the simulation models analyze the dynamic performance and consequences under different network disturbances, no studies have been found that provide strategies to optimally respond to possible global crisis situations of the gas supply. Thus, a mathematical optimization approach allows a simulation of the best possible operation of an interconnected gas infrastructure under different disruption conditions.

Therefore, this article assesses the impact of new cross-border pipelines on the security of supply in the EU natural gas transmission network, comparing the system performance for the 2009 and 2017 scenarios. This study is relevant for analyzing whether the investments made in interconnection capacity are effective enough in addressing the increasing congestion of European gas infrastructure during the winters as a result of the decreasing trend in domestic natural gas production.

The mathematical model is applied to the natural gas system of the EU-28 and some neighboring countries (i.e., Switzerland, Serbia, North Macedonia, Bosnia-Herzegovina) in order to provide possible solutions to collaboratively meet the demand of all countries in situations of supply crisis or unexpected spikes in demand due to exceptional weather conditions. Two actual cases that correspond to the extreme situations of January 2009 and 2017 are analyzed; within these cases, the scenarios of possible interruptions caused by shortages from Russia and Algeria are considered. Thus far, Russia is the largest gas supplier of the EU, with a market share of $43 \%$, while Algeria has a market share of $9 \%$ [20]. Either partial or total interruptions of gas supply from Russia to Ukraine and transit gas flows to the EU have already happened in March 2008, January 2009, June 2014, November 2015. Algeria suffered a terrorist attack to Tiguentourine gas plant in January 2013, an explosion that destroyed three of six production trains at the Skikda LNG plant in January 2017, and other incidents $[12,18,19,21]$.

The rest of this article is organized as follows: Section 2 presents the regulatory framework and the challenge of EU gas infrastructure to tackle the decline in domestic gas production. Section 3 proposes a methodology for optimal resource management of the EU gas system to cover demand. Section 4 describes the case study of the high-pressure natural gas network of the EU-28 and shows each of the proposed scenarios to calculate the utilization rate of cross-border pipelines under disruptive conditions in the extreme situations of 2009 and 2017. Sections 5 and 6 discuss the simulation results. Lastly, Section 7 draws the final conclusions of the article.

\section{Regulatory Framework and Problem Context}

The natural gas supply crisis in the EU in 2006 [22] and 2009 [12], which caused a large supply problem, particularly the one in 2009 , that affected both the population and the industrial sector, showed the lack of effect of the existing EU legislation (EU Council Directive 2004/67/EC) and triggered the development of new legislation to improve security and supply of gas in the EU [23,24]. Table 1 shows the chronology and scope of these regulatory frameworks, which shows that this regulation seeks to increase cooperation among the countries of the European Union and minimize the impact of natural gas import restrictions due to commercial, political, or technical issues [25].

Both supply crises mentioned above have shown the weakness of the natural gas infrastructure in the EU since the investments made until now in new facilities had been carried out independently due to the political, geographical, and strategic issues of each member country. However, the natural gas system is being reinforced with new facilities from a more collaborative standpoint, which addresses critical aspects such as network robustness [4,25].

Currently, the gas system in Europe (EU-28) is building new facilities that will increase the capacity of gas injection to the continent and branch transmission networks between countries. For example, the current natural gas injection capacity of the EU-28 network is $4247 \mathrm{TWh} / \mathrm{y}$, and with the completion of the Nord Stream 2 project, it will increase to $4820 \mathrm{TWh} / \mathrm{y}$, which is a $13.5 \%$ increase. Similarly, the underground storage capacity is $1132 \mathrm{TWh}$, and it is forecast to increase by $177 \mathrm{TWh}$ with an 
expected growth of $15.6 \%$ [26]. Additionally, the regasification capacity is $210 \mathrm{bcm}$ and is expected to increase to $295 \mathrm{bcm}$ [27].

Table 1. Summary of regulatory actions of the European Union (EU) since 2009.

\begin{tabular}{|c|c|c|}
\hline Supply Crisis & Regulatory Framework & Scope \\
\hline Until 2004 & Council Directive 2004/67/EC & $\begin{array}{l}\text { - Creation of the Gas Coordination Group } \\
\text { - } \quad \text { Ensure gas supply to specific customers (households) under } \\
\text { some situations } \\
\text { - Deployment of some instruments to enhance the security of } \\
\text { gas supply }\end{array}$ \\
\hline 2006 and 2009 & $\begin{array}{l}\text { First security of gas supply } \\
\text { Regulation No. 994/2010 in } \\
2010 \text { [24] }\end{array}$ & $\begin{array}{l}\text { - Establish standard definitions (particularly important the } \\
\text { definition of protected customers) } \\
\text { - Obligation to develop National Risk Assessments (RA), } \\
\text { Preventive Action Plans (PAP), and Emergency Plans (EP); } \\
\text { Adherence to Standards (Infrastructure-or N-1-Standard and } \\
\text { Supply Standard) } \\
\text { - Obligation to develop reverse flows at all cross-border points } \\
\text { (except derogation) } \\
\text { - Introduction of a vague concept of solidarity } \\
\text { - The obligation of the European Commission (EC) to assess the } \\
\text { Preventive Action Plans and the Emergency Plans }\end{array}$ \\
\hline 2017 & $\begin{array}{l}\text { On } 28 \text { October 2017, revised } \\
\text { Regulation No. (EU) } \\
\text { 2017/1938 concerning } \\
\text { measures to safeguard the } \\
\text { security of gas supply, } \\
\text { repealing Regulation (EU) } \\
\text { No. 994/2010 [28] }\end{array}$ & $\begin{array}{l}\text { - Maintain and reinforce basic concepts that have functioned } \\
\text { correctly in previous legislation: protected customers, RA, Plans, } \\
\text { Infrastructure, and Supply Standards } \\
\text { Develops the concept of solidarity, introducing the concept of } \\
\text { 'solidarity protected customer' and promotes rules to set fair } \\
\text { prices for gas shared under the principle of solidarity } \\
\text { - Formally develops the regional approach by making mandatory } \\
\text { the development of regional RAs } \\
\text { - Formal consideration of neighboring countries signatories of the } \\
\text { Energy Community Treaty }\end{array}$ \\
\hline
\end{tabular}

The previous investments were carried out to offset future projections expected by the European Union, as they have found that, while the demand will remain at current levels, there will be a reduction of up to $50 \%$ in the production of domestic gas, an increase of imports and increased dependence on foreign countries [29]. Figure 1 shows the trend in recent years for natural gas consumption, production, and imports in the EU-28 [30].

In general, the countries have four options to cover the supply:

- Produce their own supply;

- Extract gas from a storage system;

- Inject LNG into the gas transmission system;

- Use pipelines to obtain gas from other member states and third-party countries.

Countries primarily meet their demand with their own domestic resources, either production or storage. If this does not cover their energy needs, they can use gas from domestic LNG regasification plants or pipelines from neighboring or third-party countries.

LNG facilities provide greater flexibility to the operation of the gas system, especially in countries more dependent on gas imports. In the unforeseen situations of loss of operational capacity or system imbalance that need to rapidly increase the injection of external gas into the system, transmission system operators can take advantage of the use of LNG from regasification plants, as it is already available in storage tanks. 


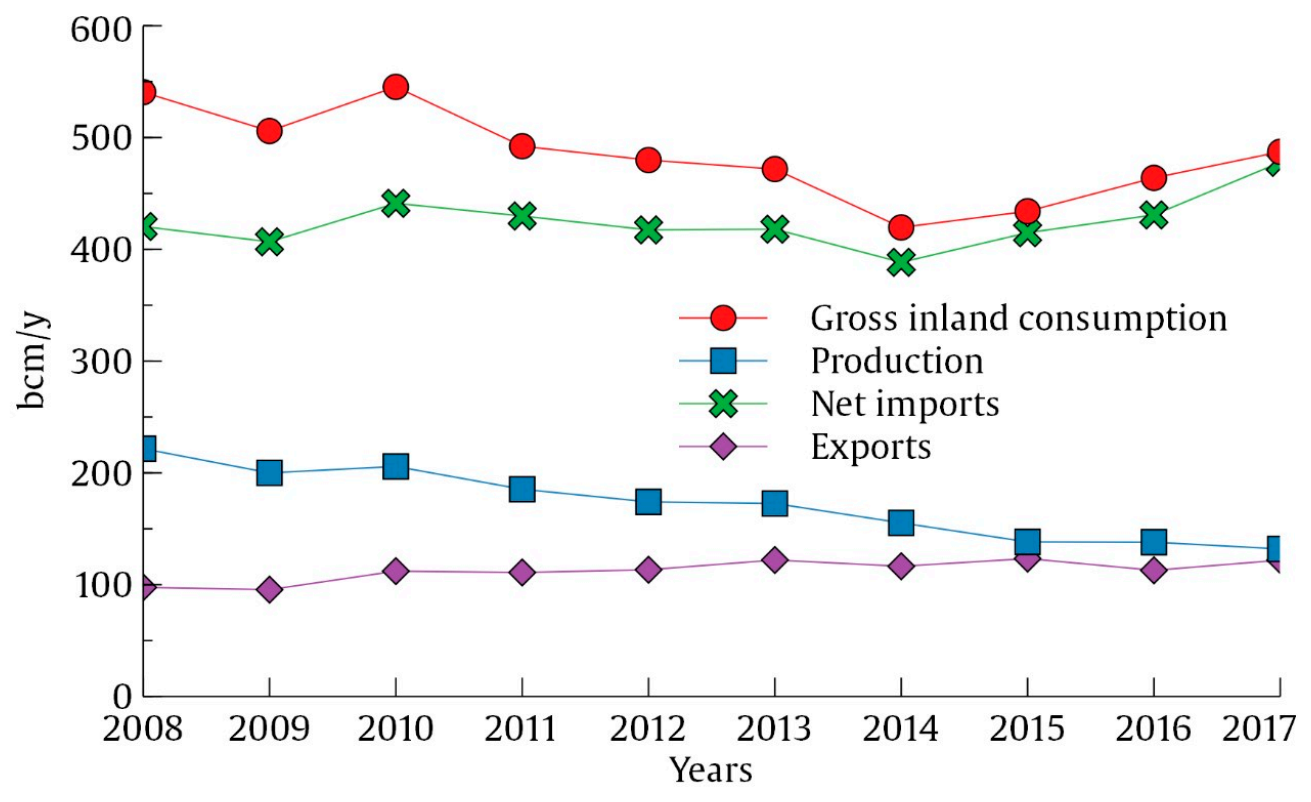

Figure 1. Natural gas trends of EU-28 [30].

\section{Methodology}

\subsection{Formulation of the Mathematical Problem}

An optimization approach is a powerful tool for studying the European gas infrastructure under different stressful conditions and analyzing whether the investments made in cross-border pipelines, from the crisis in 2009 to the peak demand situation in 2017, have improved the capacity of the transmission system. To this end, this section describes the proposed methodology to maximize the daily coverage of the natural gas demand of a group of countries interconnected in order to provide collaborative solutions against natural or political crises or a combination of both. Section 4 applies the methodology to obtain the pipeline workload of the interconnections between the countries in the EU gas system for scenarios of 2009 and 2017, and to compare the performance of the gas infrastructure at both dates.

The model considers each country as a node composed of links that represent the connections with other member countries through cross-border pipelines, which can be unidirectional or bidirectional. The same applies to natural gas resources from third-party countries supplied either through pipelines or by LNG carriers. The production and storage capacities of each country are also considered in this study (see Figure 2). For simplicity, the proposed model is a "mass balance" model in which the equations are obtained by applying the principle of mass conservation at each network node [31]. The use of hydraulic models is not possible because it would require knowledge of the parameters and technical characteristics of all networks of the countries involved [32,33].

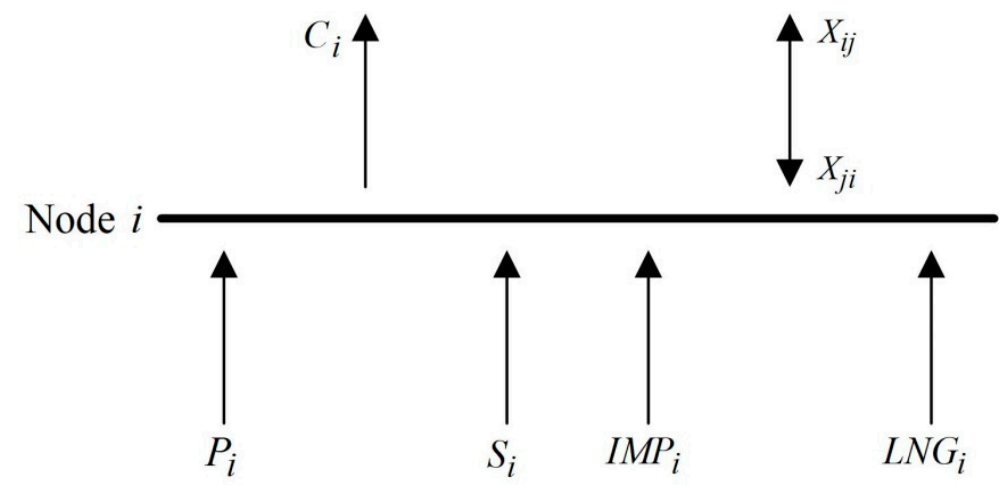

Figure 2. Incoming and outgoing natural gas flows at node $i$. 
The problem is solved as a global natural gas balance in a system whose internal borders with neighboring and third-party countries are defined that finds an equilibrium state at each node and maximizes the overall demand of the entire system. The equilibrium state is obtained using the country's resources and the exchange of resources with other countries. Equation (1) is the balance equation that describes this interaction. Table 2 presents the variables used in the model.

$$
P_{i}+S_{i}+I M P_{i}+L N G_{i}-\sum X_{i j}-C_{i}=0
$$

Table 2. Description of the variables used in the model.

\begin{tabular}{lr}
\hline$P_{i}$ & daily gas production of country $i(\mathrm{GWh} / \mathrm{d})$ \\
\hline$S_{i}$ & daily gas storage withdrawal from underground storage in country $i(\mathrm{GWh} / \mathrm{d})$ \\
\hline$I M P_{i}$ & amount of natural gas that enters the system daily through third-party country import pipeline $(\mathrm{GWh} / \mathrm{d})$ \\
\hline$L N G_{i}$ & daily liquefied natural gas injected into the pipes of country $i(\mathrm{GWh} / \mathrm{d})$ \\
\hline$X_{i j}$ & daily gas flow through pipelines between countries $i$ and $j(\mathrm{GWh} / \mathrm{d})$ \\
\hline$C_{i}$ & daily natural gas demand met in country $i(\mathrm{GWh} / \mathrm{d})$ \\
\hline
\end{tabular}

Optimization models are used in almost all fields of decision making. Since the objective of the proposed methodology is to find cooperative solutions to maximize the daily demand of natural gas of all countries in the system, a mathematical optimization problem is formulated to calculate all the variables in the model presented in Equation (1) and meet the balance conditions in the nodes and the technical limits. If the solution of the optimization problem is unique, then the proposed methodology will find the best strategy to supply the maximum demand of natural gas and take advantage of the resources available in all the countries of the system.

Thus, the objective function (Equation (2)) maximizes the daily satisfied natural gas demand $C_{i}$ in all the countries of the system:

$$
\max \sum_{i=1}^{n} C_{i}
$$

The mathematical optimization problem is completely defined by the set of constraints that must be met by the variables involved. The general constraints of the problem are shown below.

Constraint 1 . Variable $P_{i}$ is limited to values between 0 and $P_{i}^{\max }$, with the latter representing the maximum production of country $i$.

$$
0 \leq P_{i} \leq P_{i}^{\max }
$$

Constraint 2. Since the entire amount of stored gas is not available, Equation (4) limits the maximum flow $S_{i}^{\max }$ that can be extracted from the wells.

$$
0 \leq S_{i} \leq S_{i}^{\max }
$$

Constraint 3. The natural gas $I M P_{i}$ imported from third-party country import pipeline can enter and flow in the integrated network under study. $I M P_{i}^{\max }$ is the import capacity.

$$
0 \leq I M P_{i} \leq I M P_{i}^{\max }
$$

Constraint 4. LNG regasification plants are not available in some countries. Consequently, the amount of gas that is injected into the network is limited by its capacity $L N G_{i}^{\max }$.

$$
0 \leq L N G_{i} \leq L N G_{i}^{\max }
$$


Constraint 5. The amount of natural gas exchanged between countries allows them to collaboratively solve possible domestic supply shortages. Therefore, a limited amount of natural gas can be delivered through cross-border pipelines.

$$
-X_{j i}^{\max } \leq X_{i j} \leq X_{i j}^{\max }
$$

Constraint 6. In a single cross-border natural gas pipeline, the capacity of transmission in the $i \rightarrow j$ direction can be different from that in the $j \rightarrow i$ direction. Therefore, the $X_{i j}^{\max }$ and $X_{j i}^{\max }$ limits may have different values. The balance equations between countries $i$ and $j$ are represented in Equations (8) and (9).

$$
\begin{aligned}
\text { Node } i: & \rightarrow P_{i}+S_{i}+I M P_{i}+L N G_{i}-\sum X_{i j}-C_{i}=0 \\
\text { Node } j: & \rightarrow P_{j}+S_{j}+I M P_{j}+L N G_{j}+\sum X_{i j}-C_{j}=0
\end{aligned}
$$

Constraint 7. Variable $C_{i}$ ranges between 0 and $C_{i}^{\max }$ (target demand).

$$
0 \leq C_{i} \leq C_{i}^{\max }
$$

Section 3.2 shows some variations of the model and constraints caused by the strategy for demand coverage of each country.

After formulating the objective function and the constraints of the mathematical problem, it can be concluded that this problem is linear since all the variables of the problem are continuous and the equations are linear. The optimization problem is programmed in the MATLAB ${ }^{\circledR}$ (version R2019b, The MathWorks Inc., Natick, MA, USA) programming environment.

\subsection{Procedure for Pretreatment of Variables}

The cooperation model in this article proposes to share all resources among all member states of the EU, except for storage, which is considered an operational reserve of each country. In the future, when the mechanisms provided for in Regulation (EU) 2017/1938 are developed, the solidarity requirements will be greater, and it will be possible to share all resources among neighboring countries.

This model allows to share production capacities, LNG injection, and gas from third-party country import pipeline to find the optimal mathematical solution to supply the maximum gas demand possible in the European Union. Gas exchange is limited only by the capabilities of the cross-border interconnections between the countries of the system. Thus, Equations (1)-(10) must be adapted to capture the following pretreatment procedure:

Step 1. First, the domestic production available $P_{i}^{\max }$ is subtracted from the demand of each country $C_{i}^{\max }$.

Step 2. If the domestic production does not cover the demand, then the domestic storage resources available $S_{i}^{\max }$ are used.

Step 3. The remaining demand, if not satisfied in Steps 1 and 2, can be covered with any of the remaining resources available: liquefied gas from regasification plants $L N G_{i}$, foreign gas imported by pipeline $I M P_{i}$ or exchange with neighboring countries of the system $X_{i j}$.

Table 3 shows two pretreatment examples of the variables in Equations (2)-(4) before solving the optimization problem in Section 3.1 By applying the strategy above, each country uses production first (Step 1) and then storage (Step 2) to attempt to meet the demand. Case (a) shows that after applying Steps 1 and 2, there are seven units of unmet gas demand, and its coverage will be solved with mathematical optimization. 
Table 3. Examples of pretreatment of the limit values of the optimization problem variables.

\begin{tabular}{cccccc}
\hline & Case (a) & \multicolumn{3}{c}{ Case (b) } \\
\hline$C_{i}^{\max }$ & $P_{i}^{\max }$ & $S_{i}^{\max }$ & $C_{i}^{\max }$ & $P_{i}^{\max }$ & $S_{i}^{\max }$ \\
20 & 10 & 3 & 4 & 10 & 3 \\
\hline$C_{i}^{\prime}$ max & $P_{i}^{\prime \max }$ & $S_{i}^{\prime \max }$ & $C_{i}^{\prime \max }$ & $P_{i}^{\prime \max }$ & $S_{i}^{\prime \max }$ \\
7 & 0 & 0 & 0 & 6 & $3(0)$ \\
\hline
\end{tabular}

In case (b), the demand is covered by the domestic production in Step 1, and the remaining supply available (six units) is offered to other countries of the system in the joint optimization. Since storage is not necessary in this case, it is not made available to the cooperation mechanism because it is considered a strategic reserve of the country. Thus, variable $S_{i}^{\max }$ always takes the value 0 since storage is only used to meet domestic gas demand. Therefore, Equation (4) is eliminated from the formulation of this problem.

The optimization problem formulated calculates the values of the variables that correspond to the resources available for finding a solution $\left(P_{i}^{\prime}, L N G_{i}, I M P_{i}, X_{i j}\right)$ such that the greatest possible amount of unmet domestic demand is met after applying Steps 1 and 2, namely:

$$
\max \sum_{i=1}^{n} C_{i}^{\prime}
$$

\section{Case Study: High-Pressure Natural Gas Network of the EU}

\subsection{Description of the Gas Infrastructure in Europe}

This article applies the mathematical model described above to the European gas network shown in Figures 3 and 4 to compare the performance of the gas transmission network between two case studies and assess the effectiveness of the new cross-border interconnections in the system. The case studies correspond to the winter periods of 2009 (Figure 3) and 2017 (Figure 4) when the most difficult situations to cover the supply occurred. Therefore, in this study, we used the domestic demand that needs to be covered in each country $i, C_{i}^{\max }$, obtained as the daily average of the actual consumption data in January of these periods [30] (see Table 4).

Figures 3 and 4 show the network of the gas infrastructure consisting of most of the EU countries plus some neighboring states (Switzerland, Serbia, North Macedonia, Bosnia-Herzegovina), which incorporates the technical parameters of the system such as production, storage, and pipeline capacities. Some EU-28 countries are not connected to EU pipelines yet (Cyprus, Malta). Most of the countries in Figures 3 and 4 have domestic production and storage, while only a few have production but no storage, and others have storage but no production. It should be noticed that Germany and Austria have a high number of links with neighboring countries, while Finland, the Baltic countries, and Eastern Europe have fewer links and therefore are more vulnerable to possible supply constraints. Additionally, the countries of southern and western Europe have regasification plants that represent multiple alternatives to meet their domestic consumption in cases of crisis. 


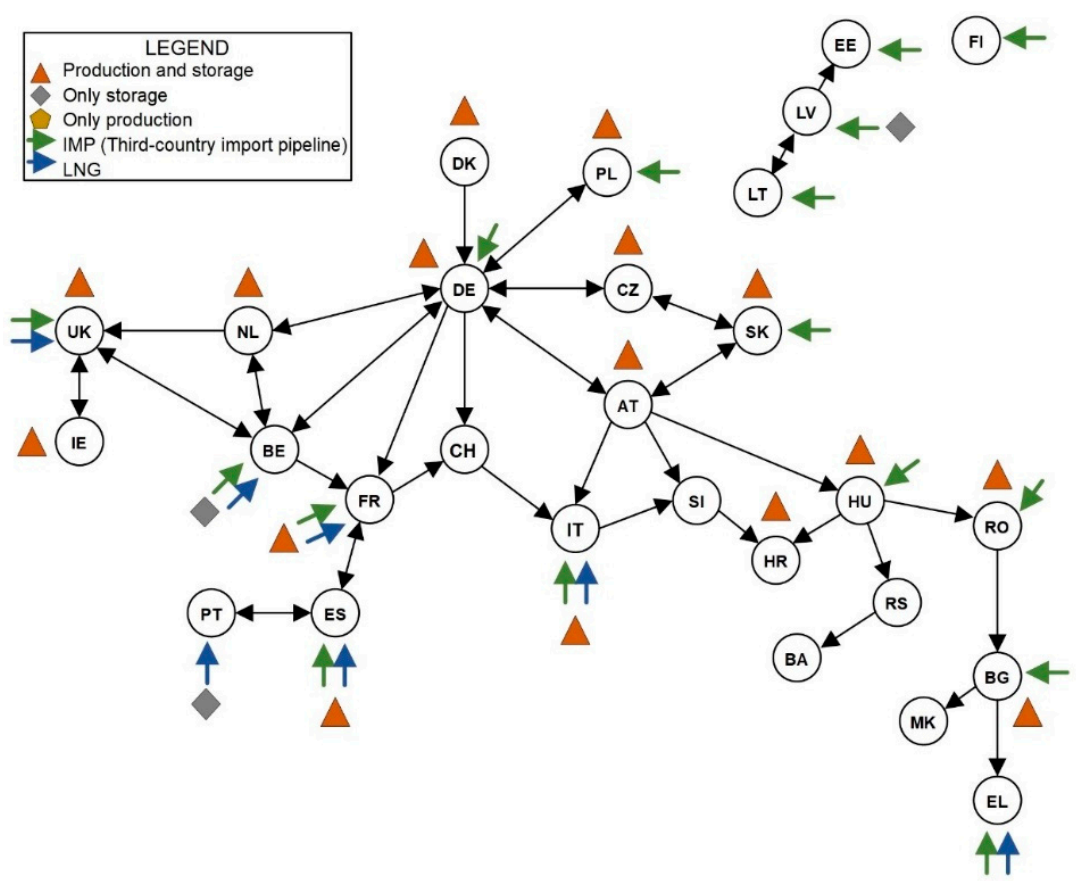

Figure 3. Gas transmission network in the European Union in 2009.

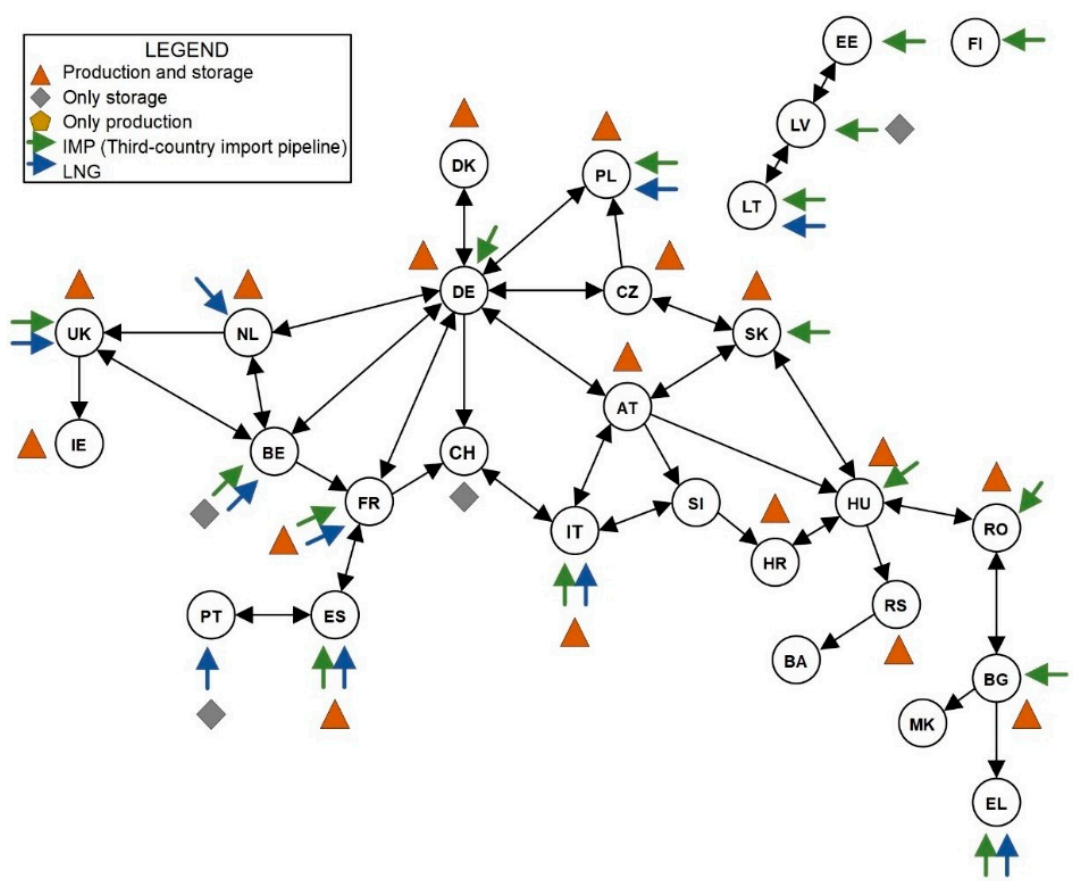

Figure 4. Gas transmission network in the European Union in 2017. 
Table 4. Data of the gas system in 2009 and 2017 (GWh/d).

\begin{tabular}{|c|c|c|c|c|c|c|c|c|c|c|c|c|c|c|c|}
\hline \multirow{2}{*}{ Node } & \multirow{2}{*}{ Country } & \multicolumn{2}{|c|}{$C^{\max }$} & \multicolumn{2}{|c|}{$P^{\max }$} & \multicolumn{2}{|c|}{$S^{\max }$} & \multicolumn{2}{|c|}{$I M P^{\max }$} & \multicolumn{2}{|c|}{$L N G^{\max }$} & \multicolumn{2}{|c|}{$X_{i j}^{\max }$} & \multicolumn{2}{|c|}{$X_{j i}^{\max }$} \\
\hline & & 2009 & 2017 & 2009 & 2017 & 2009 & 2017 & 2009 & 2017 & 2009 & 2017 & 2009 & 2017 & 2009 & 2017 \\
\hline 1 & $\mathrm{PT}$ & 143.00 & 191.34 & 0.00 & 0.00 & 86.00 & 85.68 & 0.00 & 0.00 & 192.00 & 335.89 & 113.00 & 80.00 & 191.00 & 144.00 \\
\hline 2 & ES & 1275.00 & 1248.38 & 0.00 & 1.53 & 148.00 & 214.50 & 355.00 & 732.00 & 1756.00 & 1900.00 & 226.00 & 369.00 & 223.00 & 245.00 \\
\hline 3 & FR & 2544.00 & 2642.47 & 33.00 & 1.35 & 2924.00 & 2506.00 & 570.00 & 570.00 & 780.00 & 1030.00 & 333.00 & 695.40 & 1475.00 & 1666.80 \\
\hline 4 & IT & 3557.00 & 3803.52 & 247.00 & 173.77 & 2963.00 & 2970.00 & 1410.00 & 1716.00 & 438.00 & 543.40 & 27.90 & 41.40 & 1765.50 & 1806.70 \\
\hline 5 & $\mathrm{CH}$ & 97.00 & 96.68 & 0.00 & 0.00 & 0.00 & 0.00 & 0.00 & 0.00 & 0.00 & 0.00 & 630.00 & 634.70 & 764.50 & 827.70 \\
\hline 6 & $\mathrm{DE}$ & 3816.00 & 4656.96 & 437.00 & 206.87 & 4145.00 & 7158.60 & 1367.00 & 4133.30 & 0.00 & 0.00 & 2588.50 & 5111.30 & 5037.60 & 5383.90 \\
\hline 7 & $\mathrm{BE}$ & 675.00 & 834.11 & 0.00 & 0.00 & 247.00 & 169.50 & 456.00 & 488.00 & 475.00 & 515.28 & 2241.70 & 2379.70 & 2333.50 & 2657.70 \\
\hline 8 & NL & 1892.00 & 1770.21 & 3498.00 & 1351.61 & 1934.00 & 2790.85 & 0.00 & 0.00 & 0.00 & 398.50 & 3550.40 & 4288.00 & 758.80 & 2009.10 \\
\hline 9 & DK & 209.00 & 160.11 & 342.00 & 128.60 & 170.00 & 194.40 & 0.00 & 0.00 & 0.00 & 0.00 & 33.30 & 32.70 & 0.00 & 60.60 \\
\hline 10 & $\mathrm{AT}$ & 407.00 & 533.18 & 51.00 & 40.81 & 466.00 & 1050.03 & 0.00 & 0.00 & 0.00 & 0.00 & 1771.90 & 2381.90 & 1709.70 & 2290.20 \\
\hline 11 & $\mathrm{CZ}$ & 470.00 & 509.12 & 6.00 & 6.39 & 442.00 & 703.28 & 0.00 & 0.00 & 0.00 & 0.00 & 1807.60 & 1923.10 & 1676.00 & 1690.20 \\
\hline 12 & PL & 612.00 & 813.48 & 143.00 & 135.01 & 379.00 & 574.13 & 1277.00 & 311.70 & 0.00 & 158.00 & 931.00 & 931.60 & 34.10 & 194.30 \\
\hline 13 & LT & 96.00 & 94.51 & 0.00 & 0.00 & 0.00 & 0.00 & 195.00 & 325.00 & 0.00 & 121.44 & 55.80 & 67.60 & 22.30 & 65.10 \\
\hline 14 & LV & 71.00 & 68.54 & 0.00 & 0.00 & 285.00 & 315.00 & 166.00 & 179.00 & 0.00 & 0.00 & 100.30 & 128.10 & 55.80 & 67.60 \\
\hline 15 & $\mathrm{EE}$ & 28.00 & 20.09 & 0.00 & 0.00 & 0.00 & 0.00 & 42.00 & 48.00 & 0.00 & 0.00 & 0.00 & 0.00 & 78.00 & 63.00 \\
\hline 16 & SK & 247.00 & 263.86 & 4.00 & 13.52 & 469.00 & 479.37 & 3103.00 & 2080.00 & 0.00 & 0.00 & 2869.30 & 2285.20 & 329.90 & 1110.90 \\
\hline 17 & $\mathrm{HU}$ & 594.00 & 622.63 & 75.00 & 50.34 & 574.00 & 837.42 & 624.00 & 605.00 & 0.00 & 0.00 & 391.50 & 269.60 & 128.40 & 282.60 \\
\hline 18 & SI & 35.00 & 48.86 & 0.00 & 0.00 & 0.00 & 0.00 & 0.00 & 0.00 & 0.00 & 0.00 & 53.30 & 74.80 & 102.80 & 141.00 \\
\hline 19 & HR & 102.00 & 160.69 & 76.00 & 49.10 & 53.00 & 60.57 & 0.00 & 0.00 & 0.00 & 0.00 & 0.00 & 0.00 & 256.20 & 129.30 \\
\hline 20 & $\mathrm{BH}$ & 10.00 & 9.57 & 0.00 & 0.00 & 0.00 & 0.00 & 0.00 & 0.00 & 0.00 & 0.00 & 0.00 & 0.00 & 16.69 & 15.00 \\
\hline 21 & SR & 79.87 & 20.29 & 0.00 & 14.27 & 0.00 & 56.50 & 0.00 & 0.00 & 0.00 & 0.00 & 16.69 & 15.00 & 137.90 & 142.10 \\
\hline 22 & $\mathrm{RO}$ & 418.00 & 607.89 & 357.00 & 335.13 & 25.00 & 346.55 & 360.00 & 360.00 & 0.00 & 0.00 & 360.00 & 364.10 & 50.70 & 73.10 \\
\hline 23 & BG & 85.00 & 158.38 & 3.00 & 4.12 & 36.00 & 36.20 & 651.00 & 777.00 & 0.00 & 0.00 & 132.10 & 158.30 & 360.00 & 361.60 \\
\hline 24 & FY & 23.32 & 18.36 & 0.00 & 0.00 & 0.00 & 0.00 & 0.00 & 0.00 & 0.00 & 0.00 & 0.00 & 0.00 & 23.40 & 27.40 \\
\hline 25 & EL & 106.00 & 225.88 & 0.00 & 0.00 & 0.00 & 0.00 & 30.00 & 49.00 & 148.00 & 149.87 & 0.00 & 0.00 & 108.70 & 109.30 \\
\hline 26 & IE & 183.00 & 171.72 & 0.00 & 112.25 & 27.00 & 27.00 & 0.00 & 0.00 & 0.00 & 0.00 & 89.80 & 0.00 & 321.30 & 431.70 \\
\hline 27 & UK & 3977.00 & 3677.28 & 2442.00 & 1454.12 & 925.00 & 1455.25 & 1473.00 & 1499.00 & 1777.00 & 2088.70 & 953.00 & 1061.80 & 1315.30 & 1297.40 \\
\hline 28 & FI & 161.00 & 108.89 & 0.00 & 0.00 & 0.00 & 0.00 & 250.00 & 249.00 & 0.00 & 0.00 & 0.00 & 0.00 & 0.00 & 0.00 \\
\hline
\end{tabular}


Table 4 shows in detail the technical characteristics and maximum daily capacity in each country for 2009 and 2017 [26,30,34-36]. The values of the withdrawal rate from storage $S_{i}^{\max }$ are applicable as long as the stock remains high enough (usually until mid-February). The values in Table 4 have been collected from the following data sources:

- $C_{i}^{\max }$ : Eurostat database [30];

- $S_{i}^{\max }:$ Storage database and map [26,36];

- $\quad P_{i}^{\max }, I M P_{i}^{\max }, L N G_{i}^{\max }, X_{i j}^{\max }, X_{j i}^{\max }$ : System Development Map for 2010 and $2017[34,35]$.

From Table 4 it should be noticed that in 2009, without taking into account cross-border interconnections, Switzerland, Czech Republic, Estonia, Slovenia, Bosnia-Herzegovina, Serbia, Bulgaria, Macedonia, and Ireland would not have had adequate capacity to meet their domestic demand due to a lack of storage, own production, and import capacity from third-party countries, or a combination of both, among other reasons. In addition, as shown in Table 5, the European gas network increased its import and storage capacity and experienced an increase in consumption and a decrease in domestic production until 2017 [27,30,34,36]. Due to all this, Czech Republic, Estonia and Bulgaria were able to meet its demand, and the remaining six countries, in addition to Croatia and Greece, maintained the same crisis conditions as those already experienced in 2009. Therefore, even though there were new investments, the results in Tables 4 and 5 show that these actions were insufficient.

Table 5. Evolution of the infrastructure of the gas system.

\begin{tabular}{|c|c|c|c|}
\hline \multirow{2}{*}{ Resource } & \multicolumn{2}{|c|}{ Years ${ }^{1}$} & \multirow{2}{*}{ Difference (\%) } \\
\hline & 2009 & 2017 & \\
\hline$\sum C_{i}^{\max }$ & 23,922 & 25,558 & 6.83 \\
\hline$\sum P_{i}^{\max }$ & 9723 & 6096 & -37.31 \\
\hline$\sum S_{i}^{l}$ max & 18,307 & $24,047.83$ & 31.35 \\
\hline$\sum I M^{l} P_{i}^{\max }$ & 14,338 & 16,139 & 12.56 \\
\hline$\sum L N G_{i}^{i} \max$ & 7575 & 9258 & 22.22 \\
\hline$\sum X_{i j}^{\max }$ & $21,285.09$ & $25,310.3$ & 18.91 \\
\hline
\end{tabular}

The member states of EU-28 increased their cross-border gas interconnection capacity by $18.26 \%$ between 2009 and 2017, promoted by the first European directive on security of gas supply [23,36]. Initially, in 2009, the natural gas network consisted of 42 cross-border pipelines of which eight were bi-directional. The new investments expanded the system in 2017 to 46 cross-border pipelines with 17 bi-directional interconnections.

\subsection{Scenarios}

We analyzed the case studies for January of 2009 and 2017, two difficult situations of natural gas supply experienced by European countries in the last 10 years. The crisis of 2009 was caused by a commercial conflict between Russia and Ukraine affecting the gas supply to Central Europe, while the case in 2017 was due to a cold spell. Thus, the following scenarios were analyzed:

Scenario 1: a baseline case study with 2009 data;

Scenario 2: supply crisis of 2009, including the hypothetical total disruption of gas supplied from Russia;

Scenario 3: supply crisis of 2009, including the hypothetical total disruption of gas supplied from Algeria;

Scenario 4: a baseline case study with 2017 data;

Scenario 5: supply crisis of 2017, including the hypothetical total disruption of gas supplied from Russia; 
Scenario 6: supply crisis of 2017, including the hypothetical total disruption of gas supplied from Algeria.

Results for Scenarios 1 and 4 should be only considered as a reference for comparison of cross-border utilization with respect to crisis scenarios since we are taking here the theoretical assumption of non-sharing storage resources for both baseline and crisis scenarios.

The mathematical problem of optimal management of resources and infrastructure is solved through cooperation between the member countries of the interconnected system, so that it is possible to share surplus production and gas imported from countries outside the system, both by sea and by international pipelines from non-member countries. However, as set out in national strategies for energy security, gas storage is used only to meet the domestic demand of each country.

\section{Results}

The optimal solution for each of the scenarios described in Section 4.2 was determined. The simulation was conducted in MATLAB, using a personal computer with an Intel ${ }^{\circledR}$ Core $^{\mathrm{TM}}$ i5 processor, $2.90 \mathrm{GHz}$ CPU and $12 \mathrm{~GB}$ RAM. The computational calculation time for each scenario was $2 \times 10^{-4} \mathrm{~s}$.

\subsection{Supply Crisis of 2009}

Table 6 shows the results obtained from applying the proposed mathematical optimization model to Scenarios 1 to 3. The results show that, for Scenario 1, the countries of the European gas network are able to cover $100 \%$ of the demand applying optimal management of infrastructure and resources. In contrast, in Scenario 2, Estonia, Lithuania, and Finland do not have sufficient capacity to cover their consumption, which results in a $0 \%$ satisfied demand in the three countries. This situation occurs because these countries are fully dependent on the natural gas from Russia and do not have alternative supply sources such as storage systems and regasification plants, among other facilities. In addition, other countries such as Macedonia, Bosnia-Herzegovina, Bulgaria, Poland, Serbia, and Romania are only affected since they are able to cover $45.39 \%, 73.49 \%, 74.68 \%, 90.87 \%, 92.44 \%$, and $94.29 \%$, respectively, of their demand. Interestingly, the results in Scenario 3 are identical to those of Scenario 1 , but without the supply constraints in any of the countries that constitute the critical natural gas infrastructure under study.

Furthermore, Table 7 shows the optimal use of cross-border pipelines in relation to the nominal capacity, and it can be observed that the average rates of utilization of the interconnections in Scenarios 1 to 3 are $27.70 \%, 32.67 \%$, and $27.70 \%$, respectively. In Scenario 2, the system reverses the direction of natural gas flow to the Eastern countries for compensating Russian gas interruption. For example, natural gas flow from the Netherlands to Germany changes from $-27.77 \mathrm{GWh} / \mathrm{d}$ in Scenario 1 to $184.41 \mathrm{GWh} / \mathrm{d}$ in Scenario 2, adding the unidirectional and bi-directional pipelines flow connecting both countries. As another example, the system also reverses the direction flow between Czech Republic and Slovakia from -45.36 to $113.61 \mathrm{GWh} / \mathrm{d}$. In this way, the Russian gas is replaced by other sources in the interconnected system for the gas supply to Poland, Slovakia, Hungary, Romania, and Bulgaria. In the Baltic countries, Latvia uses its resources to meet its own needs, which causes a drop in gas exchange to connected countries Lithuania and Estonia. The results in Scenario 3 are identical to those previously obtained in Scenario 1 since the most affected countries by the Algerian gas cut (Spain and Italy) have sufficient resources to cover their consumption and do not affect the gas supply of the continental system. 
Table 6. Demand coverage results for 2009 and the three proposed scenarios (GWh/d).

\begin{tabular}{|c|c|c|c|c|c|c|c|c|}
\hline \multicolumn{3}{|c|}{ Target Demand to Cover } & \multicolumn{2}{|c|}{$\begin{array}{l}\text { Scenario 1. Case } \\
2009 \text { Baseline }\end{array}$} & \multicolumn{2}{|c|}{$\begin{array}{l}\text { Scenario 2. Case } \\
2009 \text { Russian IMP } \\
\text { Interruption }\end{array}$} & \multicolumn{2}{|c|}{$\begin{array}{l}\text { Scenario 3. Case } \\
2009 \text { Algerian IMP } \\
\text { Interruption }\end{array}$} \\
\hline Country & Node & Target $C_{i}^{\max }$ & Optimal $C_{i}$ & $\begin{array}{c}\text { Covered } \\
(\%)\end{array}$ & Optimal $C_{i}$ & $\begin{array}{c}\text { Covered } \\
(\%)\end{array}$ & Optimal $C_{i}$ & $\begin{array}{c}\text { Covered } \\
(\%)\end{array}$ \\
\hline PT & 1 & 143.00 & 143.00 & $100.00 \%$ & 143.00 & $100.00 \%$ & 143.00 & $100.00 \%$ \\
\hline ES & 2 & 1275.00 & 1275.00 & $100.00 \%$ & 1275.00 & $100.00 \%$ & 1275.00 & $100.00 \%$ \\
\hline FR & 3 & 2544.00 & 2544.00 & $100.00 \%$ & 2544.00 & $100.00 \%$ & 2544.00 & $100.00 \%$ \\
\hline IT & 4 & 3557.00 & 3557.00 & $100.00 \%$ & 3557.00 & $100.00 \%$ & 3557.00 & $100.00 \%$ \\
\hline $\mathrm{CH}$ & 5 & 97.00 & 97.00 & $100.00 \%$ & 97.00 & $100.00 \%$ & 97.00 & $100.00 \%$ \\
\hline $\mathrm{DE}$ & 6 & 3816.00 & 3816.00 & $100.00 \%$ & 3816.00 & $100.00 \%$ & 3816.00 & $100.00 \%$ \\
\hline $\mathrm{BE}$ & 7 & 675.00 & 675.00 & $100.00 \%$ & 675.00 & $100.00 \%$ & 675.00 & $100.00 \%$ \\
\hline NL & 8 & 1892.00 & 1892.00 & $100.00 \%$ & 1892.00 & $100.00 \%$ & 1892.00 & $100.00 \%$ \\
\hline DK & 9 & 209.00 & 209.00 & $100.00 \%$ & 209.00 & $100.00 \%$ & 209.00 & $100.00 \%$ \\
\hline $\mathrm{AT}$ & 10 & 407.00 & 407.00 & $100.00 \%$ & 407.00 & $100.00 \%$ & 407.00 & $100.00 \%$ \\
\hline $\mathrm{CZ}$ & 11 & 470.00 & 470.00 & $100.00 \%$ & 470.00 & $100.00 \%$ & 470.00 & $100.00 \%$ \\
\hline PL & 12 & 612.00 & 612.00 & $100.00 \%$ & 556.10 & $90.87 \%$ & 612.00 & $100.00 \%$ \\
\hline $\mathrm{LT}$ & 13 & 96.00 & 96.00 & $100.00 \%$ & 0.00 & $0.00 \%$ & 96.00 & $100.00 \%$ \\
\hline $\mathrm{LV}$ & 14 & 71.00 & 71.00 & $100.00 \%$ & 71.00 & $100.00 \%$ & 71.00 & $100.00 \%$ \\
\hline $\mathrm{EE}$ & 15 & 28.00 & 28.00 & $100.00 \%$ & 0.00 & $0.00 \%$ & 28.00 & $100.00 \%$ \\
\hline SK & 16 & 247.00 & 247.00 & $100.00 \%$ & 247.00 & $100.00 \%$ & 247.00 & $100.00 \%$ \\
\hline $\mathrm{HU}$ & 17 & 594.00 & 594.00 & $100.00 \%$ & 594.00 & $100.00 \%$ & 594.00 & $100.00 \%$ \\
\hline SI & 18 & 35.00 & 35.00 & $100.00 \%$ & 35.00 & $100.00 \%$ & 35.00 & $100.00 \%$ \\
\hline $\mathrm{CR}$ & 19 & 102.00 & 102.00 & $100.00 \%$ & 102.00 & $100.00 \%$ & 102.00 & $100.00 \%$ \\
\hline $\mathrm{BH}$ & 20 & 10.00 & 10.00 & $100.00 \%$ & 7.35 & $73.49 \%$ & 10.00 & $100.00 \%$ \\
\hline SR & 21 & 79.87 & 79.87 & $100.00 \%$ & 73.84 & $92.44 \%$ & 79.87 & $100.00 \%$ \\
\hline $\mathrm{RO}$ & 22 & 418.00 & 418.00 & $100.00 \%$ & 394.15 & $94.29 \%$ & 418.00 & $100.00 \%$ \\
\hline BG & 23 & 85.00 & 85.00 & $100.00 \%$ & 63.48 & $74.68 \%$ & 85.00 & $100.00 \%$ \\
\hline FY & 24 & 23.32 & 23.32 & $100.00 \%$ & 10.59 & $45.39 \%$ & 23.32 & $100.00 \%$ \\
\hline GR & 25 & 106.00 & 106.00 & $100.00 \%$ & 106.00 & $100.00 \%$ & 106.00 & $100.00 \%$ \\
\hline IE & 26 & 183.00 & 183.00 & $100.00 \%$ & 183.00 & $100.00 \%$ & 183.00 & $100.00 \%$ \\
\hline UK & 27 & 3977.00 & 3977.00 & $100.00 \%$ & 3977.00 & $100.00 \%$ & 3977.00 & $100.00 \%$ \\
\hline FI & 28 & 161.00 & 161.00 & $100.00 \%$ & 0.00 & $0.00 \%$ & 161.00 & $100.00 \%$ \\
\hline
\end{tabular}

The balance of natural gas for each country is shown in Table 8, using the results of the flow rates between countries. For Scenario 1, Ireland and Switzerland are the countries that import the most natural gas, with 156.00 and $97.00 \mathrm{GWh} / \mathrm{d}$, respectively, while Slovakia and Poland contribute the most to neighboring countries (165.74 and $76.05 \mathrm{GWh} / \mathrm{d}$, respectively).

In Scenario 2, however, there are substantial changes in the cross-border flows in the Netherlands, Slovakia, and Poland. These differences between Scenarios 1 and 2 are caused mainly by the mutual support between these countries and the member states from Eastern Europe to offset fuel shortages in the EU countries closer to Russia (e.g., Hungary, Poland, and Slovakia). On the one hand, the Netherlands that initially exports $52.87 \mathrm{GWh} / \mathrm{d}$, in Scenario 2 increases this amount to reach $274.48 \mathrm{GWh} / \mathrm{d}$. On the other hand, the gas exchange of Slovakia reduces from 165.74 to $0.00 \mathrm{GWh} / \mathrm{d}$ and Poland changes from exporting 76.05 to purely importing $34.10 \mathrm{GWh} / \mathrm{d}$. 
Table 7. Results of cross-border gas pipeline utilization for the 2009 case.

\begin{tabular}{|c|c|c|c|c|c|c|c|c|c|}
\hline \multirow{2}{*}{ Country $i$} & \multirow{2}{*}{ Country $j$} & \multirow{2}{*}{$\begin{array}{c}X_{i j}^{\max } \\
(\mathrm{GWh} / \mathrm{d})\end{array}$} & \multirow{2}{*}{$\begin{array}{c}X_{j i}^{\max } \\
(\mathrm{GWh} / \mathrm{d})\end{array}$} & \multicolumn{2}{|c|}{ Scenario 1. Case 2009 Baseline } & \multicolumn{2}{|c|}{$\begin{array}{l}\text { Scenario 2. Case } 2009 \text { Russian IMP } \\
\text { Interruption }\end{array}$} & \multicolumn{2}{|c|}{$\begin{array}{l}\text { Scenario 3. Case 2009 Algerian IMP } \\
\text { Interruption }\end{array}$} \\
\hline & & & & $\begin{array}{c}X_{i j} \\
(\mathrm{GWh} / \mathrm{d})\end{array}$ & $\begin{array}{l}\text { Pipeline Percentage } \\
\text { Operating Data (\%) }\end{array}$ & $\begin{array}{c}X_{i j} \\
(\mathrm{GWh} / \mathrm{d})\end{array}$ & $\begin{array}{c}\text { Pipeline Percentage } \\
\text { Operating Data (\%) }\end{array}$ & $\begin{array}{c}X_{i j} \\
(\mathrm{GWh} / \mathrm{d})\end{array}$ & $\begin{array}{l}\text { Pipeline Percentage } \\
\text { Operating Data (\%) }\end{array}$ \\
\hline $\mathrm{BE}$ & FR & 820.00 & 0.00 & 37.92 & $4.62 \%$ & 43.96 & $5.36 \%$ & 37.92 & $4.62 \%$ \\
\hline $\mathrm{DE}$ & FR & 620.00 & 0.00 & 34.72 & $5.60 \%$ & 43.03 & $6.94 \%$ & 34.72 & $5.60 \%$ \\
\hline FR & $\mathrm{CH}$ & 223.00 & 0.00 & 86.96 & $38.99 \%$ & 98.46 & $44.15 \%$ & 86.96 & $38.99 \%$ \\
\hline $\mathrm{BE}$ & NL & 333.60 & 0.00 & 217.46 & $65.19 \%$ & 215.65 & $64.64 \%$ & 217.46 & $65.19 \%$ \\
\hline $\mathrm{DE}$ & $\mathrm{CH}$ & 541.50 & 0.00 & 20.93 & $3.87 \%$ & 7.96 & $1.47 \%$ & 20.93 & $3.87 \%$ \\
\hline $\mathrm{CH}$ & IT & 630.00 & 0.00 & 10.89 & $1.73 \%$ & 9.43 & $1.50 \%$ & 10.89 & $1.73 \%$ \\
\hline NL & $\mathrm{DE}$ & 1591.40 & 0.00 & 198.10 & $12.45 \%$ & 344.62 & $21.66 \%$ & 198.10 & $12.45 \%$ \\
\hline NL & UK & 420.10 & 0.00 & 107.51 & $25.59 \%$ & 120.52 & $28.69 \%$ & 107.51 & $25.59 \%$ \\
\hline NL & $\mathrm{BE}$ & 1250.50 & 0.00 & 190.59 & $15.24 \%$ & 185.20 & $14.81 \%$ & 190.59 & $15.24 \%$ \\
\hline UK & IE & 321.30 & 0.00 & 200.62 & $62.44 \%$ & 200.40 & $62.37 \%$ & 200.62 & $62.44 \%$ \\
\hline IE & UK & 89.80 & 0.00 & 44.62 & $49.69 \%$ & 44.40 & $49.44 \%$ & 44.62 & $49.69 \%$ \\
\hline $\mathrm{DE}$ & $\mathrm{AT}$ & 22.80 & 0.00 & 11.05 & $48.49 \%$ & 13.78 & $60.44 \%$ & 11.05 & $48.49 \%$ \\
\hline $\mathrm{DE}$ & PL & 34.10 & 0.00 & 21.21 & $62.20 \%$ & 34.10 & $100.00 \%$ & 21.21 & $62.20 \%$ \\
\hline DK & $\mathrm{DE}$ & 33.30 & 0.00 & 20.13 & $60.46 \%$ & 24.90 & $74.78 \%$ & 20.13 & $60.46 \%$ \\
\hline SI & $\mathrm{HR}$ & 53.30 & 0.00 & 0.00 & $0.00 \%$ & 0.00 & $0.00 \%$ & 0.00 & $0.00 \%$ \\
\hline IT & SI & 27.90 & 0.00 & 15.56 & $55.77 \%$ & 17.08 & $61.23 \%$ & 15.56 & $55.77 \%$ \\
\hline $\mathrm{AT}$ & IT & 1135.50 & 0.00 & 4.67 & $0.41 \%$ & 7.66 & $0.67 \%$ & 4.67 & $0.41 \%$ \\
\hline $\mathrm{AT}$ & SI & 74.90 & 0.00 & 19.44 & $25.95 \%$ & 17.92 & $23.92 \%$ & 19.44 & $25.95 \%$ \\
\hline $\mathrm{AT}$ & $\mathrm{DE}$ & 112.80 & 0.00 & 46.18 & $40.94 \%$ & 25.25 & $22.39 \%$ & 46.18 & $40.94 \%$ \\
\hline $\mathrm{AT}$ & $\mathrm{HU}$ & 128.40 & 0.00 & 69.81 & $54.37 \%$ & 128.40 & $100.00 \%$ & 69.81 & $54.37 \%$ \\
\hline PL & $\mathrm{DE}$ & 931.00 & 0.00 & 97.26 & $10.45 \%$ & 0.00 & $0.00 \%$ & 97.26 & $10.45 \%$ \\
\hline $\mathrm{LV}$ & $\mathrm{EE}$ & 78.00 & 0.00 & 0.00 & $0.00 \%$ & 0.00 & $0.00 \%$ & 0.00 & $0.00 \%$ \\
\hline $\mathrm{CZ}$ & $\mathrm{DE}$ & 1160.00 & 0.00 & 183.23 & $15.80 \%$ & 138.29 & $11.92 \%$ & 183.23 & $15.80 \%$ \\
\hline $\mathrm{HU}$ & HR & 202.90 & 0.00 & 0.00 & $0.00 \%$ & 0.00 & $0.00 \%$ & 0.00 & $0.00 \%$ \\
\hline $\mathrm{HU}$ & $\mathrm{RO}$ & 50.70 & 0.00 & 11.18 & $22.06 \%$ & 47.22 & $93.13 \%$ & 11.18 & $22.06 \%$ \\
\hline $\mathrm{HU}$ & RS & 137.90 & 0.00 & 89.87 & $65.17 \%$ & 81.18 & $58.87 \%$ & 89.87 & $65.17 \%$ \\
\hline $\mathrm{RO}$ & BG & 360.00 & 0.00 & 18.41 & $5.11 \%$ & 35.07 & $9.74 \%$ & 18.41 & $5.11 \%$ \\
\hline BG & EL & 108.70 & 0.00 & 0.00 & $0.00 \%$ & 0.00 & $0.00 \%$ & 0.00 & $0.00 \%$ \\
\hline BG & MK & 23.40 & 0.00 & 23.32 & $99.66 \%$ & 10.59 & $45.24 \%$ & 23.32 & $99.66 \%$ \\
\hline RS & BA & 16.69 & 0.00 & 10.00 & $59.91 \%$ & 7.35 & $44.03 \%$ & 10.00 & $59.91 \%$ \\
\hline
\end{tabular}


Table 7. Cont.

\begin{tabular}{|c|c|c|c|c|c|c|c|c|c|}
\hline \multirow{2}{*}{ Country $i$} & \multirow{2}{*}{ Country $j$} & \multirow{2}{*}{$\begin{array}{c}X_{i j}^{\max } \\
(\mathrm{GWh} / \mathrm{d})\end{array}$} & \multirow{2}{*}{$\begin{array}{c}X_{j i}^{\max } \\
(\mathrm{GWh} / \mathrm{d})\end{array}$} & \multicolumn{2}{|c|}{ Scenario 1. Case 2009 Baseline } & \multicolumn{2}{|c|}{$\begin{array}{l}\text { Scenario 2. Case } 2009 \text { Russian IMP } \\
\text { Interruption }\end{array}$} & \multicolumn{2}{|c|}{$\begin{array}{l}\text { Scenario 3. Case 2009 Algerian IMP } \\
\text { Interruption }\end{array}$} \\
\hline & & & & $\begin{array}{c}X_{i j} \\
(\mathrm{GWh} / \mathrm{d})\end{array}$ & $\begin{array}{l}\text { Pipeline Percentage } \\
\text { Operating Data (\%) }\end{array}$ & $\begin{array}{c}X_{i j} \\
(\mathrm{GWh} / \mathrm{d})\end{array}$ & $\begin{array}{c}\text { Pipeline Percentage } \\
\text { Operating Data (\%) }\end{array}$ & $\begin{array}{c}X_{i j} \\
(\mathrm{GWh} / \mathrm{d})\end{array}$ & $\begin{array}{l}\text { Pipeline Percentage } \\
\text { Operating Data (\%) }\end{array}$ \\
\hline $\mathrm{BE}$ & $\mathrm{DE}$ & 0.80 & 0.00 & 0.39 & $48.57 \%$ & 0.34 & $41.89 \%$ & 0.39 & $48.57 \%$ \\
\hline SK & AT & 1141.10 & 0.00 & 153.25 & $13.43 \%$ & 133.84 & $11.73 \%$ & 153.25 & $13.43 \%$ \\
\hline ES & FR & 35.00 & -110.00 & 14.32 & $40.92 \%$ & 11.48 & $32.79 \%$ & 14.32 & $40.92 \%$ \\
\hline ES & PT & 191.00 & -113.00 & -7.21 & $6.38 \%$ & -5.76 & $5.10 \%$ & -7.21 & $6.38 \%$ \\
\hline $\mathrm{BE}$ & $\mathrm{DE}$ & 281.90 & -451.30 & -62.97 & $13.95 \%$ & 51.42 & $18.24 \%$ & -62.97 & $13.95 \%$ \\
\hline NL & $\mathrm{DE}$ & 288.40 & -425.20 & -225.87 & $53.12 \%$ & -160.21 & $37.68 \%$ & -225.87 & $53.12 \%$ \\
\hline UK & $\mathrm{BE}$ & 631.70 & -805.40 & -23.49 & $2.92 \%$ & 30.67 & $4.85 \%$ & -23.49 & $2.92 \%$ \\
\hline $\mathrm{DE}$ & $\mathrm{CZ}$ & 408.00 & -492.00 & 159.87 & $39.18 \%$ & 273.90 & $67.13 \%$ & 159.87 & $39.18 \%$ \\
\hline $\mathrm{DE}$ & AT & 85.60 & -146.00 & 8.68 & $10.14 \%$ & 51.84 & $60.56 \%$ & 8.68 & $10.14 \%$ \\
\hline $\mathrm{CZ}$ & SK & 155.60 & -1268.00 & -45.36 & $3.58 \%$ & 113.61 & $73.01 \%$ & -45.36 & $3.58 \%$ \\
\hline $\mathrm{LV}$ & LT & 22.30 & -55.80 & 0.00 & $0.00 \%$ & 0.00 & $0.00 \%$ & 0.00 & $0.00 \%$ \\
\hline $\mathrm{AT}$ & SK & 174.30 & -460.20 & 32.87 & $18.86 \%$ & 20.23 & $11.61 \%$ & 32.87 & $18.86 \%$ \\
\hline \multicolumn{5}{|c|}{ Pipeline average operation data (\%) } & $27.70 \%$ & - & $32.67 \%$ & - & $27.70 \%$ \\
\hline
\end{tabular}


Table 8. Cross-border flows balance in each country for the 2009 case (GWh/d).

\begin{tabular}{|c|c|c|c|}
\hline Country & $\begin{array}{c}\text { Scenario 1. Case } 2009 \\
\text { Baseline }\end{array}$ & $\begin{array}{c}\text { Scenario 2. Case } 2009 \\
\text { Russian IMP Interruption }\end{array}$ & $\begin{array}{c}\text { Scenario 3. Case } 2009 \\
\text { Algerian IMP Interruption }\end{array}$ \\
\hline- & $\sum X_{i j}$ & $\sum X_{i j}$ & $\sum X_{i j}$ \\
\hline $\mathrm{PT}$ & 7.21 & 5.76 & 7.21 \\
\hline ES & 7.11 & 5.71 & 7.11 \\
\hline FR & 0.00 & 0.00 & 0.00 \\
\hline IT & 0.00 & 0.00 & 0.00 \\
\hline $\mathrm{CH}$ & -97.00 & -97.00 & -97.00 \\
\hline DE & 0.00 & 0.00 & 0.00 \\
\hline $\mathrm{BE}$ & 25.69 & 95.50 & 25.69 \\
\hline NL & 52.87 & 274.48 & 52.87 \\
\hline DK & 20.13 & 24.90 & 20.13 \\
\hline AT & 0.00 & 0.00 & 0.00 \\
\hline $\mathrm{CZ}$ & -22.00 & -22.00 & -22.00 \\
\hline PL & 76.05 & -34.10 & 76.05 \\
\hline $\mathrm{LT}$ & 0.00 & 0.00 & 0.00 \\
\hline LV & 0.00 & 0.00 & 0.00 \\
\hline $\mathrm{EE}$ & 0.00 & 0.00 & 0.00 \\
\hline SK & 165.74 & 0.00 & 165.74 \\
\hline $\mathrm{HU}$ & 31.24 & 0.00 & 31.24 \\
\hline SI & -35.00 & -35.00 & -35.00 \\
\hline CR & 0.00 & 0.00 & 0.00 \\
\hline $\mathrm{BH}$ & -10.00 & -7.35 & -10.00 \\
\hline SR & -79.87 & -73.84 & -79.87 \\
\hline $\mathrm{RO}$ & 7.22 & -12.15 & 7.22 \\
\hline BG & 4.91 & -24.48 & 4.91 \\
\hline FY & -23.32 & -10.59 & -23.32 \\
\hline GR & 0.00 & 0.00 & 0.00 \\
\hline $\mathrm{IE}$ & -156.00 & -156.00 & -156.00 \\
\hline UK & 25.01 & 66.14 & 25.01 \\
\hline FI & 0.00 & 0.00 & 0.00 \\
\hline
\end{tabular}

\subsection{Supply Crisis of 2017}

Table 9 shows the findings from Scenarios 4-7 during the crisis of 2017. In Scenario 4, the global system is able to cover all of the natural gas demand in the member countries. Otherwise, in Scenario 5 , where there is a hypothetical gas supply interruption from Russia, Finland is the most affected country with $0.00 \%$ demand coverage, while Macedonia, Bulgaria, and Greece cannot cover all their consumption since their demand coverages are $41.29 \%, 44.09 \%$, and 94.42 , respectively. Similar to the results of Scenario 4, a gas disruption from Algeria, as simulated in Scenario 6, does not produce any disturbance to meet natural gas demand.

The optimal load of the interconnections is presented in Table 10. The pipeline workload is $31.53 \%$, $33.93 \%$, and $31.53 \%$ in Scenarios 4, 5, and 6, respectively. It should be noted that in Scenario 5, as a result of the interruption of the gas supplied by Russia, there is an overall increase in the utilization of cross-border pipelines, mainly between eastern countries like Hungary and Romania and between Baltic republics (Latvia and Lithuania), with an increase from $54.16 \%$ to $100.00 \%$ in the first case and from $0 \%$ to $35.64 \%$ for the second interconnection. Meanwhile, the event in Scenario 6 is neutralized by Spain and Italy due to their available regasification plants and storage, which eliminates the impact on the coverage of demand in the integrated network.

Furthermore, Table 11 shows the natural gas balance in each country of the coupled system. In Scenario 5, Slovakia, United Kingdom, Belgium, and Bulgaria have the greatest fluctuation in cross-border flows in order to compensate Russian natural gas interruption. On the one hand, Slovakia that initially exports $164.90 \mathrm{GWh} / \mathrm{d}$ changes its status to $0 \mathrm{GWh} / \mathrm{d}$. On the other hand, United Kingdom and Belgium with 26.32 and $207.10 \mathrm{GWh} / \mathrm{d}$ of exported gas initially increase their exports up to 140.42 
and $254.89 \mathrm{GWh} / \mathrm{d}$ to the countries located to the geographic east of the gas system. Finally, Bulgaria that initially exports $6.47 \mathrm{GWh} / \mathrm{d}$ in Scenario 5 changes its status until it becomes a net importing country with $29.52 \mathrm{GWh} / \mathrm{d}$. Additionally, in Scenario 6 there are no notable changes in the countries that are part of the system because the interruption of Algeria mainly affects Spain and Italy; however, these two nations have the potential to satisfy their consumption and avoid effects on third parties.

Table 9. Demand coverage results for 2017 and the three proposed scenarios (GWh/d).

\begin{tabular}{|c|c|c|c|c|c|c|c|c|}
\hline \multicolumn{3}{|c|}{ Target Demand to Cover } & \multicolumn{2}{|c|}{$\begin{array}{c}\text { Scenario 4. Case } \\
2017 \text { Baseline }\end{array}$} & \multicolumn{2}{|c|}{$\begin{array}{c}\text { Scenario 5. Case } \\
2017 \text { Russian IMP } \\
\text { Interruption }\end{array}$} & \multicolumn{2}{|c|}{$\begin{array}{c}\text { Scenario 6. Case } \\
\text { 2017 Algerian IMP } \\
\text { Interruption }\end{array}$} \\
\hline Country & Node & Target $C_{i}^{\max }$ & Optimal $C_{i}$ & $\begin{array}{l}\text { Covered } \\
(\%)\end{array}$ & Optimal $C_{i}$ & $\begin{array}{l}\text { Covered } \\
(\%)\end{array}$ & Optimal $C_{i}$ & $\begin{array}{c}\text { Covered } \\
(\%)\end{array}$ \\
\hline $\mathrm{PT}$ & 1 & 191.34 & 191.34 & $100.00 \%$ & 191.34 & $100.00 \%$ & 191.34 & $100.00 \%$ \\
\hline ES & 2 & 1248.38 & 1248.38 & $100.00 \%$ & 1248.38 & $100.00 \%$ & 1248.38 & $100.00 \%$ \\
\hline FR & 3 & 2642.47 & 2642.47 & $100.00 \%$ & 2642.47 & $100.00 \%$ & 2642.47 & $100.00 \%$ \\
\hline IT & 4 & 3803.52 & 3803.52 & $100.00 \%$ & 3803.52 & $100.00 \%$ & 3803.52 & $100.00 \%$ \\
\hline $\mathrm{CH}$ & 5 & 96.68 & 96.68 & $100.00 \%$ & 96.68 & $100.00 \%$ & 96.68 & $100.00 \%$ \\
\hline DE & 6 & 4656.96 & 4656.96 & $100.00 \%$ & 4656.96 & $100.00 \%$ & 4656.96 & $100.00 \%$ \\
\hline $\mathrm{BE}$ & 7 & 834.11 & 834.11 & $100.00 \%$ & 834.11 & $100.00 \%$ & 834.11 & $100.00 \%$ \\
\hline NL & 8 & 1770.21 & 1770.21 & $100.00 \%$ & 1770.21 & $100.00 \%$ & 1770.21 & $100.00 \%$ \\
\hline DK & 9 & 160.11 & 160.11 & $100.00 \%$ & 160.11 & $100.00 \%$ & 160.11 & $100.00 \%$ \\
\hline AT & 10 & 533.18 & 533.18 & $100.00 \%$ & 533.18 & $100.00 \%$ & 533.18 & $100.00 \%$ \\
\hline $\mathrm{CZ}$ & 11 & 509.12 & 509.12 & $100.00 \%$ & 509.12 & $100.00 \%$ & 509.12 & $100.00 \%$ \\
\hline PL & 12 & 813.48 & 813.48 & $100.00 \%$ & 813.48 & $100.00 \%$ & 813.48 & $100.00 \%$ \\
\hline $\mathrm{LT}$ & 13 & 94.51 & 94.51 & $100.00 \%$ & 94.51 & $100.00 \%$ & 94.51 & $100.00 \%$ \\
\hline LV & 14 & 68.54 & 68.54 & $100.00 \%$ & 68.54 & $100.00 \%$ & 68.54 & $100.00 \%$ \\
\hline $\mathrm{EE}$ & 15 & 24.09 & 24.09 & $100.00 \%$ & 24.09 & $100.00 \%$ & 24.09 & $100.00 \%$ \\
\hline SK & 16 & 263.86 & 263.86 & $100.00 \%$ & 263.86 & $100.00 \%$ & 263.86 & $100.00 \%$ \\
\hline $\mathrm{HU}$ & 17 & 622.63 & 622.63 & $100.00 \%$ & 622.63 & $100.00 \%$ & 622.63 & $100.00 \%$ \\
\hline SI & 18 & 48.86 & 48.86 & $100.00 \%$ & 48.86 & $100.00 \%$ & 48.86 & $100.00 \%$ \\
\hline $\mathrm{CR}$ & 19 & 160.69 & 160.69 & $100.00 \%$ & 160.69 & $100.00 \%$ & 160.69 & $100.00 \%$ \\
\hline $\mathrm{BH}$ & 20 & 9.57 & 9.57 & $100.00 \%$ & 9.57 & $100.00 \%$ & 9.57 & $100.00 \%$ \\
\hline SR & 21 & 20.29 & 20.29 & $100.00 \%$ & 20.29 & $100.00 \%$ & 20.29 & $100.00 \%$ \\
\hline $\mathrm{RO}$ & 22 & 607.89 & 607.89 & $100.00 \%$ & 607.89 & $100.00 \%$ & 607.89 & $100.00 \%$ \\
\hline BG & 23 & 158.38 & 158.38 & $100.00 \%$ & 69.84 & $44.09 \%$ & 158.38 & $100.00 \%$ \\
\hline FY & 24 & 18.36 & 18.36 & $100.00 \%$ & 7.58 & $41.29 \%$ & 18.36 & $100.00 \%$ \\
\hline GR & 25 & 225.88 & 225.88 & $100.00 \%$ & 213.28 & $94.42 \%$ & 225.88 & $100.00 \%$ \\
\hline $\mathrm{IE}$ & 26 & 171.72 & 171.72 & $100.00 \%$ & 171.72 & $100.00 \%$ & 171.72 & $100.00 \%$ \\
\hline UK & 27 & 3677.28 & 3677.28 & $100.00 \%$ & 3677.28 & $100.00 \%$ & 3677.28 & $100.00 \%$ \\
\hline FI & 28 & 108.89 & 108.89 & $100.00 \%$ & 0.00 & $0.00 \%$ & 108.89 & $100.00 \%$ \\
\hline
\end{tabular}


Table 10. Results of cross-border gas pipelines utilization for the 2017 case.

\begin{tabular}{|c|c|c|c|c|c|c|c|c|c|}
\hline \multirow{2}{*}{ Country $i$} & \multirow{2}{*}{ Country $j$} & \multirow{2}{*}{$\begin{array}{c}X_{i j}^{\max } \\
(\mathrm{GWh} / \mathrm{d})\end{array}$} & \multirow{2}{*}{$\begin{array}{c}X_{j i}^{\max } \\
(\mathrm{GWh} / \mathrm{d})\end{array}$} & \multicolumn{2}{|c|}{ Scenario 4. Case 2017 Baseline } & \multicolumn{2}{|c|}{$\begin{array}{l}\text { Scenario 5. Case } 2017 \text { Russian IMP } \\
\text { Interruption }\end{array}$} & \multicolumn{2}{|c|}{$\begin{array}{l}\text { Scenario 6. Case } 2017 \text { Algerian IMP } \\
\text { Interruption }\end{array}$} \\
\hline & & & & $\begin{array}{c}X_{i j} \\
(\mathrm{GWh} / \mathrm{d})\end{array}$ & $\begin{array}{l}\text { Pipeline Percentage } \\
\text { Operating Data (\%) }\end{array}$ & $\begin{array}{c}X_{i j} \\
(\mathrm{GWh} / \mathrm{d})\end{array}$ & $\begin{array}{c}\text { Pipeline Percentage } \\
\text { Operating Data (\%) }\end{array}$ & $\begin{array}{c}X_{i j} \\
(\mathrm{GWh} / \mathrm{d})\end{array}$ & $\begin{array}{l}\text { Pipeline Percentage } \\
\text { Operating Data (\%) }\end{array}$ \\
\hline $\mathrm{BE}$ & FR & 870.00 & 0.00 & 140.48 & $16.15 \%$ & 127.78 & $14.69 \%$ & 140.48 & $16.15 \%$ \\
\hline $\mathrm{DE}$ & FR & 571.80 & 0.00 & 65.08 & $11.38 \%$ & 51.43 & $8.99 \%$ & 65.08 & $11.38 \%$ \\
\hline FR & $\mathrm{CH}$ & 260.40 & 0.00 & 68.97 & $26.49 \%$ & 73.99 & $28.41 \%$ & 68.97 & $26.49 \%$ \\
\hline $\mathrm{BE}$ & NL & 122.00 & 0.00 & 86.65 & $71.02 \%$ & 84.51 & $69.27 \%$ & 86.65 & $71.02 \%$ \\
\hline $\mathrm{DE}$ & $\mathrm{CH}$ & 554.40 & 0.00 & 34.47 & $6.22 \%$ & 30.49 & $5.50 \%$ & 34.47 & $6.22 \%$ \\
\hline $\mathrm{CH}$ & IT & 634.70 & 0.00 & 14.81 & $2.33 \%$ & 14.77 & $2.33 \%$ & 14.81 & $2.33 \%$ \\
\hline NL & $\mathrm{DE}$ & 1466.80 & 0.00 & 679.95 & $46.36 \%$ & 743.30 & $50.68 \%$ & 679.95 & $46.36 \%$ \\
\hline NL & UK & 494.00 & 0.00 & 105.78 & $21.41 \%$ & 80.66 & $16.33 \%$ & 105.78 & $21.41 \%$ \\
\hline NL & $\mathrm{BE}$ & 1041.50 & 0.00 & 196.56 & $18.87 \%$ & 132.75 & $12.75 \%$ & 196.56 & $18.87 \%$ \\
\hline UK & IE & 431.70 & 0.00 & 32.47 & $7.52 \%$ & 32.47 & $7.52 \%$ & 32.47 & $7.52 \%$ \\
\hline $\mathrm{DE}$ & AT & 24.20 & 0.00 & 13.47 & $55.64 \%$ & 12.88 & $53.23 \%$ & 13.47 & $55.64 \%$ \\
\hline SI & HR & 53.30 & 0.00 & 14.77 & $27.71 \%$ & 15.24 & $28.60 \%$ & 14.77 & $27.71 \%$ \\
\hline $\mathrm{AT}$ & IT & 1150.50 & 0.00 & 10.66 & $0.93 \%$ & 7.72 & $0.67 \%$ & 10.66 & $0.93 \%$ \\
\hline $\mathrm{AT}$ & SI & 112.50 & 0.00 & 46.21 & $41.07 \%$ & 48.59 & $43.19 \%$ & 46.21 & $41.07 \%$ \\
\hline $\mathrm{AT}$ & $\mathrm{HU}$ & 153.10 & 0.00 & 25.33 & $16.54 \%$ & 36.84 & $24.06 \%$ & 25.33 & $16.54 \%$ \\
\hline $\mathrm{LV}$ & $\mathrm{EE}$ & 63.00 & 0.00 & 0.00 & $0.00 \%$ & 24.09 & $38.24 \%$ & 0.00 & $0.00 \%$ \\
\hline $\mathrm{CZ}$ & $\mathrm{DE}$ & 906.90 & 0.00 & 311.06 & $34.30 \%$ & 352.31 & $38.85 \%$ & 311.06 & $34.30 \%$ \\
\hline $\mathrm{HU}$ & $\mathrm{HR}$ & 76.00 & 0.00 & 36.25 & $47.70 \%$ & 35.78 & $47.08 \%$ & 36.25 & $47.70 \%$ \\
\hline $\mathrm{HU}$ & RS & 142.10 & 0.00 & 9.57 & $6.73 \%$ & 9.57 & $6.73 \%$ & 9.57 & $6.73 \%$ \\
\hline $\mathrm{RO}$ & BG & 360.00 & 0.00 & 51.45 & $14.29 \%$ & 62.49 & $17.36 \%$ & 51.45 & $14.29 \%$ \\
\hline BG & EL & 109.30 & 0.00 & 27.01 & $24.71 \%$ & 14.40 & $13.18 \%$ & 27.01 & $24.71 \%$ \\
\hline BG & MK & 27.40 & 0.00 & 18.36 & $67.01 \%$ & 7.58 & $27.66 \%$ & 18.36 & $67.01 \%$ \\
\hline RS & BA & 15.00 & 0.00 & 9.57 & $63.80 \%$ & 9.57 & $63.80 \%$ & 9.57 & $63.80 \%$ \\
\hline $\mathrm{DE}$ & $\mathrm{CZ}$ & 1081.20 & 0.00 & 610.57 & $56.47 \%$ & 684.96 & $63.35 \%$ & 610.57 & $56.47 \%$ \\
\hline $\mathrm{CZ}$ & PL & 28.00 & 0.00 & 12.03 & $42.96 \%$ & 11.79 & $42.12 \%$ & 12.03 & $42.96 \%$ \\
\hline SK & $\mathrm{HU}$ & 127.00 & 0.00 & 43.63 & $34.35 \%$ & 60.00 & $47.25 \%$ & 43.63 & $34.35 \%$ \\
\hline FR & $\mathrm{DE}$ & 270.00 & 0.00 & 179.13 & $66.35 \%$ & 185.07 & $68.54 \%$ & 179.13 & $66.35 \%$ \\
\hline IT & $\mathrm{CH}$ & 12.90 & 0.00 & 8.04 & $62.36 \%$ & 6.97 & $54.03 \%$ & 8.04 & $62.36 \%$ \\
\hline $\mathrm{AT}$ & $\mathrm{DE}$ & 6.90 & 0.00 & 3.49 & $50.57 \%$ & 3.37 & $48.88 \%$ & 3.49 & $50.57 \%$ \\
\hline ES & FR & 225.00 & -165.00 & 42.54 & $18.91 \%$ & 79.85 & $35.49 \%$ & 42.54 & $18.91 \%$ \\
\hline ES & $\mathrm{PT}$ & 144.00 & -80.00 & -16.38 & $20.48 \%$ & -22.45 & $28.06 \%$ & -16.38 & $20.48 \%$ \\
\hline $\mathrm{BE}$ & $\mathrm{DE}$ & 313.10 & -320.10 & 171.29 & $54.71 \%$ & 204.19 & $65.21 \%$ & 171.29 & $54.71 \%$ \\
\hline NL & $\mathrm{DE}$ & 889.70 & -1615.90 & -790.77 & $48.94 \%$ & -712.42 & $44.09 \%$ & -790.77 & $48.94 \%$ \\
\hline UK & $\mathrm{BE}$ & 630.10 & -803.40 & 99.63 & $15.81 \%$ & 188.61 & $29.93 \%$ & 99.63 & $15.81 \%$ \\
\hline
\end{tabular}


Table 10. Cont.

\begin{tabular}{|c|c|c|c|c|c|c|c|c|c|}
\hline \multirow{2}{*}{ Country $i$} & \multirow{2}{*}{ Country $j$} & \multirow{2}{*}{$\begin{array}{c}X_{i j}^{\max } \\
(\mathrm{GWh} / \mathrm{d})\end{array}$} & \multirow{2}{*}{$\begin{array}{c}X_{j i}^{\max } \\
(\mathrm{GWh} / \mathrm{d})\end{array}$} & \multicolumn{2}{|c|}{ Scenario 4. Case 2017 Baseline } & \multicolumn{2}{|c|}{$\begin{array}{l}\text { Scenario 5. Case } 2017 \text { Russian IMP } \\
\text { Interruption }\end{array}$} & \multicolumn{2}{|c|}{$\begin{array}{l}\text { Scenario 6. Case 2017 Algerian IMP } \\
\text { Interruption }\end{array}$} \\
\hline & & & & $\begin{array}{c}X_{i j} \\
(\mathrm{GWh} / \mathrm{d})\end{array}$ & $\begin{array}{l}\text { Pipeline Percentage } \\
\text { Operating Data (\%) }\end{array}$ & $\begin{array}{c}X_{i j} \\
(\mathrm{GWh} / \mathrm{d})\end{array}$ & $\begin{array}{c}\text { Pipeline Percentage } \\
\text { Operating Data (\%) }\end{array}$ & $\begin{array}{c}X_{i j} \\
(\mathrm{GWh} / \mathrm{d})\end{array}$ & $\begin{array}{l}\text { Pipeline Percentage } \\
\text { Operating Data (\%) }\end{array}$ \\
\hline $\mathrm{DE}$ & AT & 581.30 & -638.70 & -301.75 & $47.25 \%$ & -137.75 & $21.57 \%$ & -301.75 & $47.25 \%$ \\
\hline $\mathrm{CZ}$ & SK & 696.80 & -400.40 & 239.00 & $34.30 \%$ & 276.95 & $39.75 \%$ & 239.00 & $34.30 \%$ \\
\hline LV & LT & 65.10 & -67.60 & 0.00 & $0.00 \%$ & -24.09 & $35.64 \%$ & 0.00 & $0.00 \%$ \\
\hline $\mathrm{AT}$ & SK & 320.20 & -1684.70 & -373.97 & $22.20 \%$ & -221.39 & $13.14 \%$ & -373.97 & $22.20 \%$ \\
\hline $\mathrm{BE}$ & NL & 271.20 & -396.00 & 104.88 & $38.67 \%$ & 159.79 & $58.92 \%$ & 104.88 & $38.67 \%$ \\
\hline IT & SI & 28.50 & -21.50 & 17.42 & $61.13 \%$ & 15.52 & $54.44 \%$ & 17.42 & $61.13 \%$ \\
\hline $\mathrm{DE}$ & DK & 60.60 & -32.70 & 0.00 & $0.00 \%$ & 0.00 & $0.00 \%$ & 0.00 & $0.00 \%$ \\
\hline $\mathrm{DE}$ & PL & 166.30 & -931.60 & -12.03 & $1.29 \%$ & -11.79 & $1.27 \%$ & -12.03 & $1.29 \%$ \\
\hline $\mathrm{HU}$ & RO & 51.50 & -2.50 & 27.89 & $54.16 \%$ & 51.50 & $100.00 \%$ & 27.89 & $54.16 \%$ \\
\hline SK & $\mathrm{CZ}$ & 73.10 & -93.90 & -13.70 & $14.60 \%$ & -4.45 & $4.73 \%$ & -13.70 & $14.60 \%$ \\
\hline BG & $\mathrm{RO}$ & 21.60 & -1.60 & 12.56 & $58.14 \%$ & 10.99 & $50.86 \%$ & 12.56 & $58.14 \%$ \\
\hline $\mathrm{DE}$ & $\mathrm{CZ}$ & 135.50 & -197.50 & -34.78 & $17.61 \%$ & -39.46 & $19.98 \%$ & -34.78 & $17.61 \%$ \\
\hline \multicolumn{5}{|c|}{ Pipeline average operation data (\%) } & $31.53 \%$ & - & $33.93 \%$ & - & $31.53 \%$ \\
\hline
\end{tabular}


Table 11. Cross-border flows balance in each country for the 2017 case (GWh/d).

\begin{tabular}{|c|c|c|c|}
\hline Country & $\begin{array}{c}\text { Scenario 4. Case } 2017 \\
\text { Baseline }\end{array}$ & $\begin{array}{c}\text { Scenario 5. Case } 2017 \\
\text { Russian IMP Interruption }\end{array}$ & $\begin{array}{c}\text { Scenario 6. Case } 2017 \\
\text { Algerian IMP Interruption }\end{array}$ \\
\hline- & $\sum X_{i j}$ & $\sum X_{i j}$ & $\sum X_{i j}$ \\
\hline $\mathrm{PT}$ & 16.38 & 22.45 & 16.38 \\
\hline ES & 26.16 & 57.41 & 26.16 \\
\hline FR & 0.00 & 0.00 & 0.00 \\
\hline IT & 0.00 & 0.00 & 0.00 \\
\hline $\mathrm{CH}$ & -96.68 & -96.68 & -96.68 \\
\hline $\mathrm{DE}$ & -179.13 & -185.07 & -179.13 \\
\hline $\mathrm{BE}$ & 207.10 & 254.89 & 207.10 \\
\hline NL & 0.00 & 0.00 & 0.00 \\
\hline DK & 0.00 & 0.00 & 0.00 \\
\hline $\mathrm{AT}$ & 0.00 & 0.00 & 0.00 \\
\hline $\mathrm{CZ}$ & 0.00 & 0.00 & 0.00 \\
\hline PL & 0.00 & 0.00 & 0.00 \\
\hline $\mathrm{LT}$ & 0.00 & 24.09 & 0.00 \\
\hline LV & 0.00 & 0.00 & 0.00 \\
\hline $\mathrm{EE}$ & 0.00 & -24.09 & 0.00 \\
\hline SK & 164.90 & 0.00 & 164.90 \\
\hline $\mathrm{HU}$ & 4.76 & 0.00 & 4.76 \\
\hline SI & -48.86 & -48.86 & -48.86 \\
\hline HR & -51.02 & -51.02 & -51.02 \\
\hline BA & -9.57 & -9.57 & -9.57 \\
\hline RS & 0.00 & 0.00 & 0.00 \\
\hline $\mathrm{RO}$ & 11.00 & 0.00 & 11.00 \\
\hline $\mathrm{BG}$ & 6.47 & -29.52 & 6.47 \\
\hline MK & -18.36 & -7.58 & -18.36 \\
\hline EL & -27.01 & -14.40 & -27.01 \\
\hline IE & -32.47 & -32.47 & -32.47 \\
\hline UK & 26.32 & 140.42 & 26.32 \\
\hline FI & 0.00 & 0.00 & 0.00 \\
\hline
\end{tabular}

\section{Results Discussion}

\subsection{Regarding Coverage of Demand}

In the actual situations described for 2009 and 2017 cases, some countries would not be able to meet their demand without using the interconnections with neighboring countries of the system (see Table 4). Moreover, for 2017, there is an uneven increase in the demand of the countries, by an average of $7.43 \%$, compared to 2009. For example, in the case of Bulgaria, there is an increased consumption by $86.33 \%$ compared to 2009 , while in other countries like Serbia it decreases by $74.60 \%$. The initial assessment performed with our methodology shows that an efficient and cooperative management between members of the system would better cover the overall demand in the integrated gas network by using the existing interconnections, in both cases (Scenarios 1 and 4).

When analyzing crisis situations in Scenarios 2 and 5, the direction of natural gas flow changes in some Central European countries for compensating a hypothetical Russian gas interruption. As a consequence, most Baltic and Balkan countries might not be able to meet their demand even using interconnections. For example, in Scenarios 1 and 4, Slovakia is a transit country with a contribution to the system of 165.74 and $164.90 \mathrm{GWh} / \mathrm{d}$, respectively, but in case of an interruption of gas supply from Russia (Scenarios 2 and 5), Slovakia uses its resources to supply itself and stops supporting neighboring countries.

Our findings show an improvement in the European gas system between 2009 and 2017 since the total percentage of covered demand increases from $98.14 \%$ to $99.06 \%$ in the case of a hypothetical gas shortage from Russia (Scenarios 2 and 5). In 2009 there are nine countries which cannot meet their gas 
demand, but in 2017 there are only four. Estonia and Lithuania are the most favored countries since they increase their covered demand from $0 \%$ to $100 \%$. The most affected country is Finland since it covers $0 \%$ of its domestic gas demand in both scenarios.

By contrast, the disruption of gas from Algeria (Scenarios 3 and 6) does not affect the overall demand of the European infrastructure because Italy and Spain are the only countries that import from Algeria; nevertheless, these two countries can meet their consumption targets because they have sufficient storage systems and high regasification capacity to cover the deficit produced by this event both in 2009 and 2017 cases.

\subsection{Regarding the Interconnections}

Between 2009 and 2017 there have been investments made in new facilities to improve the capacity of the high-pressure natural gas system in the European Union and better respond to potential crises. The interconnection capacity among EU-28 countries has improved as a whole of $18.91 \%$, not only building some new pipelines but also converting some unidirectional pipes into bi-directional.

However, the new infrastructures would be not able to guarantee $100 \%$ of the natural gas supply in all member countries in case of a Russian gas cut. A more detailed analysis has shown that an increase in demand in some countries would result in others having difficulties in covering their demand due to their high dependency on those neighboring countries whose consumption has increased.

An overall increase in the utilization of cross-border pipelines is observed when an interruption of the gas supplied by Russia is simulated for both 2009 and 2017. On the one hand, taking the results from Scenarios 1 and 2, the average pipeline workload in 2009 grows from $27.77 \%$ to $32.67 \%$, i.e., an increase of $17.95 \%$. On the other hand, our results from Scenarios 4 and 5 show values of interconnection use in 2017 of $31.53 \%$ and $33.93 \%$ respectively, i.e., an increase of $7.59 \%$. The investments made in new cross-border capacity have not improved the pipeline average operation between 2009 and 2017, but they would allow a better response in the case of a hypothetical gas shortage from Russia.

\section{Conclusions}

A large fraction of the gas consumed in Europe is imported from third-party countries, and the recent past has witnessed some major gas cuts for commercial or political reasons. This article analyzed the investments made in interconnection capacity between the EU member states to address the challenges of resource management in case of external supply disruptions and increasing congestion of European gas infrastructure as a result of declining domestic natural gas production and growing demand. To achieve this goal, the utilization rate of the cross-border pipelines of the EU natural gas transmission network was calculated in two scenarios of actual supply crisis of 2009 and 2017, using a mathematical optimization approach. The proposed optimization model maximized the demand coverage under different hypothetical crisis conditions by sharing production, LNG, and imports from third-party countries. The methodology incorporated the technical data of the critical gas infrastructure, such as production capacity, storage and regasification plants, and used cross-border pipelines as cooperation mechanisms.

Among the main findings, some countries are not self-sufficient and depend on gas supply from neighboring countries to meet their domestic demand. Additionally, the results showed that the addition of the new assets has improved the energy security of the European gas network, since a smaller number of countries would fail to meet their demand in case of external disruptions of gas imports. However, the interconnections are becoming more loaded. This conclusion is of particular relevance since previous research on gas infrastructure upgrades identified the improvement in demand coverage, but not the issue with pipeline workload [12]. Additionally, hypothetical supply disruptions from Russia and Algeria were simulated, and the results showed that Russian gas has the highest impact on meeting overall gas demand in the European network. It is also worth mentioning that the proposed methodology could provide an optimal solution to cover better the overall demand in the 
integrated gas network by managing cooperatively the interconnected national gas infrastructure and resources in case of potential supply crises.

The results derived from this research could be useful for EU policy-makers as they show that investments made in cross-border pipelines do not decongest the EU gas network, although interconnection capacity between EU-28 countries has improved by $18.91 \%$, not only building some new pipelines but also converting some unidirectional pipes into bi-directional. The European natural gas system must, therefore, be further strengthened with new cross-border facilities for the robust operation of this critical infrastructure. Further studies should be carried out, taking into account the exchange of storage resources between countries. Other hypothetical scenarios could be analyzed for assessing the risk of European security of gas supply under a cooperative paradigm.

Author Contributions: Conceptualization, Y.R. and J.M.Y.; methodology, Y.R., J.B. and J.M.Y.; investigation, Y.R., J.B. and J.M.Y.; validation: J.M.Y. and R.B.-L.; writing—original draft preparation, Y.R. and J.M.Y.; writing一review and editing, Y.R., J.B., J.M.Y. and R.B.-L. All authors have read and agreed to the published version of the manuscript.

Funding: This research received no external funding.

Conflicts of Interest: The authors declare no conflict of interest.

\section{References}

1. Zeniewski, P. A Long-term View of Natural Gas Security in the European Union. Available online: https: //www.iea.org/commentaries/a-long-term-view-of-natural-gas-security-in-the-european-union (accessed on 14 May 2020).

2. Birol, F. Analysis and forecasts to 2023. Available online: https://www.iea.org/reports/gas-2018 (accessed on 14 May 2020).

3. Buttler, A.; Spliethoff, H. Current status of water electrolysis for energy storage, grid balancing and sector coupling via power-to-gas and power-to-liquids: A review. Renew. Sustain. Energy Rev. 2018, 82, 2440-2454. [CrossRef]

4. Carvalho, R.; Buzna, L.; Bono, F.; Masera, M.; Arrowsmith, D.K.; Helbing, D. Resilience of Natural Gas Networks during Conflicts, Crises and Disruptions. PLoS ONE 2014, 9, e90265. [CrossRef] [PubMed]

5. Buzna, L.; Carvalho, R.; Bono, F.; Masera, M.; Arrowsmith, D.K. Congestion dependencies in the European gas pipeline network during crises. In Proceedings of the 2014 Complexity in Engineering (COMPENG), Barcelona, Spain, 16-17 June 2014; pp. 1-5.

6. Flouri, M.; Karakosta, C.; Kladouchou, C.; Psarras, J. How does a natural gas supply interruption affect the EU gas security? A Monte Carlo simulation. Renew. Sustain. Energy Rev. 2015, 44, 785-796. [CrossRef]

7. Richter, P.M.; Holz, F. All quiet on the eastern front? Disruption scenarios of Russian natural gas supply to Europe. Energy Policy 2015, 80, 177-189. [CrossRef]

8. Welsch, M.; Pye, S.; Keles, D.; Faure-Schuyer, A.; Dobbins, A.; Shivakumar, A.; Deane, P.; Howells, M. Europe's Energy Transition. Insights for Policy Making; Elsevier: Amsterdam, The Nederland, 2017; p. 354.

9. Mitrova, T.; Boersma, T.; Galkina, A. Some future scenarios of Russian natural gas in Europe. Energy Strategy Rev. 2016, 11-12, 19-28. [CrossRef]

10. Austvik, O.G. The Energy Union and security-of-gas supply. Energy Policy 2016, 96, 372-382. [CrossRef]

11. Eser, P.; Chokani, N.; Abhari, R. Impact of Nord Stream 2 and LNG on gas trade and security of supply in the European gas network of 2030. Appl. Energy 2019, 238, 816-830. [CrossRef]

12. Rodríguez-Gómez, N.; Zaccarelli, N.; Bolado-Lavín, R. European ability to cope with a gas crisis. Comparison between 2009 and 2014. Energy Policy 2016, 97, 461-474. [CrossRef]

13. Pambour, K.A.; Bolado-Lavin, R.; Dijkema, G.P.J. An integrated transient model for simulating the operation of natural gas transport systems. J. Nat. Gas Sci. Eng. 2016, 28, 672-690. [CrossRef]

14. Voropai, N.I.; Senderov, S.M.; Edelev, A.V. Detection of "bottlenecks" and ways to overcome emergency situations in gas transportation networks on the example of the European gas pipeline network. Energy 2012, 42, 3-9. [CrossRef]

15. Monforti, F.; Szikszai, A. A MonteCarlo approach for assessing the adequacy of the European gas transmission system under supply crisis conditions. Energy Policy 2010, 38, 2486-2498. [CrossRef] 
16. Wangdee, W. Bulk Electric System Reliability Simulation and Application; University of Saskatchewan: Saskatoon, SK, Canada, 2005.

17. Deane, J.P.; Ciaráin, M.Ó.; Gallachóir, B.Ó. An integrated gas and electricity model of the EU energy system to examine supply interruptions. Appl. Energy 2017, 193, 479-490. [CrossRef]

18. Bilgin, M. Geopolitics of European natural gas demand: Supplies from Russia, Caspian and the Middle East. Energy Policy 2009, 37, 4482-4492. [CrossRef]

19. Pambour, K.A.; Cakir Erdener, B.; Bolado-Lavin, R.; Dijkema, G.P.J. SAInt—A novel quasi-dynamic model for assessing security of supply in coupled gas and electricity transmission networks. Appl. Energy 2017, 203, 829-857. [CrossRef]

20. EU. Quarterly Report on European Gas Market. Available online: https://data.europa.eu/euodp/es/data/ dataset/european-gas-market-reports (accessed on 14 May 2020).

21. Stulberg, A.N. Natural gas and the Russia-Ukraine crisis: Strategic restraint and the emerging Europe-Eurasia gas network. Energy Res. Soc. Sci. 2017, 24, 71-85. [CrossRef]

22. Stern, J. The Russian-Ukrainian Gas Crisis of January 2006; Oxford Institute for Energy Studies: Oxford, UK, 2006; Available online: https://www.ogel.org/article.asp?key=2045 (accessed on 19 March 2020).

23. López, S.; Sánchez-Peñuela, J.B. El nuevo reglamento europeo de seguridad de suministro de gas. Econ. Ind. 2017, 1, 155-162.

24. EU. Regulation (EU) No 994/2010 of the European Parliament and of the Council of 20 October 2010 Concerning Measures to Safeguard Security of Gas Supply and Repealing Council Directive 2004/67/EC. Available online: http://data.europa.eu/eli/reg/2010/994/oj (accessed on 14 May 2020).

25. Kinsara, R.A.; Matbouli, Y.T. Strategic analysis of the European natural Gas Crisis. In Proceedings of the 2016 IEEE International Conference on Systems, Man, and Cybernetics (SMC), Budapest, Hungary, 9-12 October 2016; pp. 004367-004372.

26. GIE. Storage Map. 2018. Available online: https://www.gie.eu/download/maps/2018/GIE_STOR_2018_A0_ 1189x841_FULL_FINAL.pdf (accessed on 14 May 2020).

27. GIE. LNG Investment Database. Available online: https://www.gie.eu/index.php/gie-publications/databases/ lng-investment-database (accessed on 14 May 2020).

28. EU. Regulation (EU) 2017/1938 of the European Parliament and of the Council of 25 October 2017 Concerning Measures to Safeguard the Security of Gas Supply and Repealing Regulation (EU) No 994/2010. Available online: https://eur-lex.europa.eu/eli/reg/2017/1938/oj (accessed on 14 May 2020).

29. EU. EU Reference Scenario 2016. Available online: https://ec.europa.eu/energy/sites/ener/files/documents/ 20160713\%20draft_publication_REF2016_v13.pdf (accessed on 14 May 2020).

30. Eurostat. European Database. Available online: https://ec.europa.eu/eurostat/data/database (accessed on 14 May 2020).

31. De Wolf, D.; Smeers, Y. The gas transmission problem solved by an extension of the Simplex algorithm. Manag. Sci. 2003, 1454-1465. [CrossRef]

32. Ayala, H.; Luis, F.; Leong, C.Y. A robust linear-pressure analog for the analysis of natural gas transportation networks. J. Nat. Gas Sci. Eng. 2013, 14, 174-184. [CrossRef]

33. Leong, C.Y.; Ayala, H.; Luis, F. Hybrid Approach by Use of Linear Analogs for Gas-Network Simulation With Multiple Components. Oil Gas Facil. 2013, 3, 76-88. [CrossRef]

34. GIE. System Development Map. 2010. Available online: https://www.entsog.eu/sites/default/files/2018--10/ ENTSOG_SYSDEV_MAP2010.pdf (accessed on 14 May 2020).

35. GIE. System Development Map. 2017. Available online: https://www.entsog.eu/sites/default/files/2018--12/ ENTSOG_GIE_SYSDEV_2017--2018_1600x1200_FULL.pdf (accessed on 14 May 2020).

36. GIE. Storage Database. Available online: https://www.gie.eu/index.php/gie-publications/databases/storagedatabase (accessed on 14 May 2020).

(C) 2020 by the authors. Licensee MDPI, Basel, Switzerland. This article is an open access article distributed under the terms and conditions of the Creative Commons Attribution (CC BY) license (http://creativecommons.org/licenses/by/4.0/). 